Article

\title{
Photoactivatable Surface-Functionalized Diatom Microalgae for Colorectal Cancer Targeted Delivery and Enhanced Cytotoxicity of Anticancer Complexes
}

\author{
Joachim Delasoie $^{1}\left(\mathbb{D}\right.$, Philippe Schiel $^{1}$, Sandra Vojnovic ${ }^{2}$, Jasmina Nikodinovic-Runic ${ }^{2}{ }^{\circledR}$ and \\ Fabio Zobi ${ }^{1, *(\mathbb{D})}$ \\ 1 Department of Chemistry, Fribourg University, Chemin du Musée 9, 1700 Fribourg, Switzerland; \\ joachim.delasoie@unifr.ch (J.D.); philippe.schiel@gmail.com (P.S.) \\ 2 Institute of molecular Genetics and Genetic Engineering, University of Belgrade, Vojvode Stepe 444a, \\ 11042 Belgrade, Serbia; sandravojnovic@imgge.bg.ac.rs (S.V.); jasmina.nikodinovic@imgge.bg.ac.rs (J.N.-R.) \\ * Correspondence: fabio.zobi@unifr.ch
}

Received: 17 April 2020; Accepted: 20 May 2020; Published: 25 May 2020

\begin{abstract}
Systemic toxicity and severe side effects are commonly associated with anticancer chemotherapies. New strategies based on enhanced drug selectivity and targeted delivery to cancer cells while leaving healthy tissue undamaged can reduce the global patient burden. Herein, we report the design, synthesis and characterization of a bio-inspired hybrid multifunctional drug delivery system based on diatom microalgae. The microalgae's surface was chemically functionalized with hybrid vitamin $B_{12}$-photoactivatable molecules and the materials further loaded with highly active rhenium(I) tricarbonyl anticancer complexes. The constructs showed enhanced adherence to colorectal cancer (CRC) cells and slow release of the chemotherapeutic drugs. The overall toxicity of the hybrid multifunctional drug delivery system was further enhanced by photoactivation of the microalgae surface. Depending on the construct and anticancer drug, a 2-fold increase in the cytotoxic efficacy of the drug was observed upon light irradiation. The use of this targeted drug delivery strategy, together with selective spatial-temporal light activation, may lead to lower effective concentration of anticancer drugs, thereby reducing medication doses, possible side effects and overall burden for the patient.
\end{abstract}

Keywords: diatoms; drug delivery system; HCT-116; porphyrin; vitamin $\mathrm{B}_{12}$; carbon monoxide releasing molecule; rhenium; cancer

\section{Introduction}

Targeted drug delivery for the confined treatment of colonic diseases is becoming increasingly important to address locally life-threatening disorders like colorectal cancer (CRC). Colon-focused drug delivery (CFDD) permits direct treatment at the disorder site, lowers drug dosing and decreases the chance of systemic side-effects. Indeed, most available chemotherapeutics are poorly tolerated by patients and induce severe side effects that are unbearable in many cases. CFDD is a strategy actively pursued to address inflammatory bowel diseases [1-3] and most importantly CRC. Indeed, despite advances in diagnostic and therapeutic modalities, CRC is the third most commonplace cause of cancer-related deaths worldwide. Generally, CRC originates from the inner wall of the colorectal epithelium, develops as a polyp and finally spreads by invading nearby lymph nodes and other organs. As pointed out in recent reviews, issues like the path of the gastro-intestinal (GI) tract, dynamic $\mathrm{pH}$ changes and the inability to discern healthy tissues from cancerous ones must be overcome in order to develop effective materials for CFDD treatment [4-6]. 
Different porous materials such as zeolites, nanoparticles, dendrimers/polymers, nano-hydrogels or metal organic frameworks were shown to be prospective tools in the field of drug delivery systems (DDSs) and cancer-targeted treatments [7-17]. In terms of material design for colon-focused drug delivery, several approaches have been described. Salleh et al., e.g., evaluated the performance of gelatin-coated type $\mathrm{Y}$ zeolite for the controlled release of the anticancer drug zerumbone [18] encapsulated in its pores, showing sustained and prolonged drug release over $24 \mathrm{~h} \mathrm{[19].} \mathrm{Li} \mathrm{and}$ coworkers addressed CFDD via a nano-in-micro dual drug delivery platform composed of halloysite nanotubes and a $\mathrm{pH}$-responsive polymer. This clay mineral was loaded with atorvastatin and celecoxib, which were released only at pH 7.4 and effectively inhibited colon cancer cell proliferation [20]. $\mathrm{Xu}$ et al. recently presented up-conversion nanoparticles (UCNPs) to trigger cancer immunotherapy in CRC by NIR-induced photodynamic therapy (PDT) to directly destroy tumor cells and to stimulate immune responses by triggering the maturation of dendritic cells and secretion of cytokines [21]. Others have used gold- [22] and folate-coated nanoparticles for active CFDD of nanotherapeutics [23]. Finally, different authors have used reactive oxygen species (ROS)-responsive nanoplatforms and polymers as drug delivery systems with excellent results [6].

We have recently begun to develop CFDD materials based on environmentally sustainable, abundant and inexpensive diatom microalgae (DEMs) [24] with the aim of designing an innovative structure able to simultaneously target the tumor site and release loaded chemotherapeutics in its immediate proximity [25]. DEMs, as the fossil frustules of diatoms, recently gained attention for their use in drug delivery due to their biocompatibility and ability to shuttle and slowly release different drugs [26-29]. Diatoms are enclosed in a three-dimensional, highly ordered silica shell (called frustule) and represent an inexpensive and well-engineered source of microporous silica [30-33]. Our original proof of concept relied on the chemical functionalization of the diatom microalgae's surface with vitamin $\mathrm{B}_{12}$, which allowed specific binding of the material to CRC cells and, therefore, discrimination between healthy and diseased tissues. The next step in our concept is illustrated in Figure 1. This bio-inspired hybrid multifunctional drug delivery system is modified by the introduction of photoactivatable units (orange spheres in Figure 1), which are envisioned to act in concert with the loaded chemotherapeutic drugs (light blue squares) in order to (a) sensitize the tumor and (b) lower the overall drug dose needed for effective treatment.
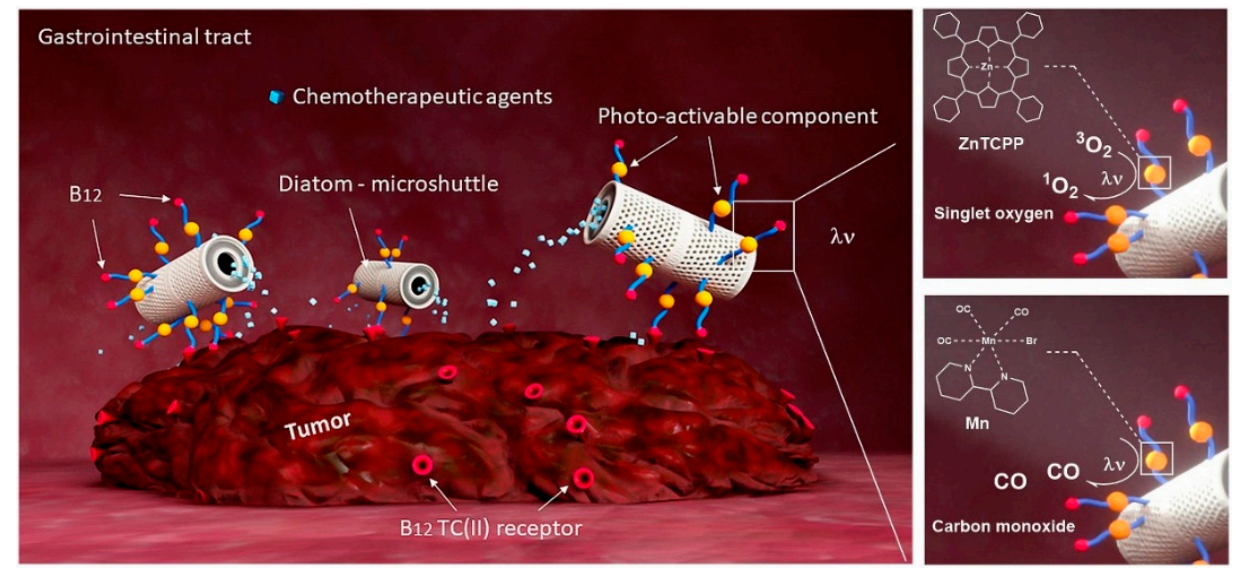

Figure 1. Left. Concept showing the bio-inspired hybrid multifunctional drug delivery system described in this study. Natural diatom microalgae (DEMs) are functionalized at their surface with photoactivatable elements (orange spheres) linked to vitamin $\mathrm{B}_{12}$ (red spheres) acting as the outer tumor-targeting layer. The construct can be loaded with a chemotherapeutic drug (light blue squares) to be selectively delivered to the tumor site in the intestinal tract. Once DEMs are bound to the tumor mass, the chemotherapeutic drug is slowly released. In addition to that, the micro-capsules can be photoactivated to generate a toxic $\mathrm{CO}$ or ${ }^{1} \mathrm{O}_{2}$, sensitizing the tumor to the treatment. Right. Photo-induced chemical reactions at the surface of the diatom microalgae (vide infra for more details). 
For this purpose, two complex bio-vehicles were synthetized. In both cases, the outer layer of the microalgae was still composed of cobalamin (vitamin $B_{12}$, red spheres in Figure 1). The inner layers of the constructs were built with either a chemical photosensitizer (for photodynamic therapy, PDT) or a photo-triggered CO-releasing molecule (see right inserts in Figure 1). Photodynamic therapy is a minimally invasive treatment incorporating three different components: a light source, a chemical photosensitizer (PS) and tissue oxygen. This process aims to generate endogenously highly toxic singlet oxygen $\left({ }^{1} \mathrm{O}_{2}\right)$ and reactive oxygen species (ROS) upon light irradiation [34]. The produced excited-state singlet oxygen species induce cell apoptosis in tumors $[35,36]$. The advantages of this technique are the spatio-temporal controlled activity allowed by the photoactivation and the potential to be combined with other therapeutic treatments as chemotherapy, surgery, radiotherapy or immunotherapy [37]. As chemical photosensitizer for our hybrid multifunctional drug delivery system, we chose porphyrins, as they absorb at several wavelengths in the visible region (Soret band in the blue and $Q$-bands in the red) and show long-lived triplet states allowing high ${ }^{1} \mathrm{O}_{2}$ quantum yields [38-41]. Furthermore, coordination of metal ions such as $\mathrm{Zn}^{2+}, \mathrm{Ga}^{3+}$ or $\mathrm{Si}^{4+}$ allows tuning ${ }^{1} \mathrm{O}_{2}$ generation capacities of porphyrins, giving long excited-state lifetimes and permitting high singlet oxygen yields [42]. As a photo-triggered CO-releasing molecule, we selected a (2,2'-bipyridine)-3,4'-dicarboxylic acid manganese tricarbonyl complex. Such types of complexes (vide infra for detailed chemistry) are well known to decompose if photo-irradiated, liberating in the process carbon monoxide. $\mathrm{CO}$, in turn, is known to exhibit antiproliferative and cytotoxic effects in cancer treatments [43-47]. In this contribution, we describe the preparation of these new bio-inspired hybrid multifunctional drug delivery systems. In addition to that, we detail CRC cellular interaction of the same, their drug-loading and -releasing properties, and their effects on the proliferation of CRC HCT-116 cells in the dark and when photoactivated.

\section{Materials and Methods}

\subsection{Chemicals and Materials}

Diatomaceous earth microalgae (DEMs), in the form of Celatom ${ }^{\circledR} \mathrm{Fw}-14$, were obtained from Applied minerals Ltd. (Burton, Staffordshire, UK). Pyrrole was purchased from Acros Organics (Hanover Township, NJ, US) and 4-carboxybenzaldehyde from Fluka Chemicals. 1-ethyl-3-(3-dimethylaminopropyl)carbodiimide (EDC), N-hydroxysuccinimide (NHS), tetra-phenylporphyrin (TPP) and 9,10-dimethylanthracene (DMA) were purchased from TCI Europe (Zwijndrecht, Belgium). N,N-dimethylformamide (DMF), Dimethyl sulfoxide (DMSO), Sodium dithionite, Triethylamine (TEA), Vitamin $B_{12}$ (cyanocobalamin), 1,1'-Carbonyl-di-(1,2,4-triazole) (CDT), 4,7,10-trioxa-1,13-tridecanediamine (PEG linker) and zinc acetate dihydrate were delivered by Sigma-Aldrich (Buchs, Switzerland). (3-aminopropyl)triethoxysilane (APTES), $\mathrm{H}_{2} \mathrm{SO}_{4}$ and $\mathrm{HCl}$ were purchased from Honey-well Research chemicals (Bucharest, Romania). $\mathrm{H}_{2} \mathrm{O}_{2}$ and glycerol were purchased from Reactolab SA (Servion, Switzerland). Rhenium complexes (1 and $\mathbf{2}$ ) used as drug models were synthetized as described in a previous paper [48]. Simulated gastric fluid (SGF) was prepared as described by Coughlin et al. [49].

\subsection{Characterization Techniques}

NMR analyses were performed with a Bruker Advance III (Bruker Switzerland AG, Fällenden, Switzerland) $500 \mathrm{MHz}$, or $400 \mathrm{MHz}$. The corresponding ${ }^{1} \mathrm{H}$ chemical shifts are reported relative to residual solvent protons and carbons. Mass analyses were performed either using ESI-MS on a Bruker FTMS 4.7-T Apex II in positive mode or MALDI with a Bruker UltrafleXtreme MALDI-TOF (Bruker Switzerland AG, Fällenden, Switzerland). UV-Vis spectra were measured using a Jasco V730 spectrophotometer (Echallens, Switzerland). Solid-state UV-Vis spectra were measured using a Perkin Elmer UV/VIS/NIR Spectrometer Lambda 900 with a Perkin Elmer 150 mm Int. Sphere (Schwerzenbach, Switzerland). The dry powder samples (ca. $5 \mathrm{mg}$ ) were dispersed between two quartz slits and stacked before being analyzed. IR spectra were measured using a Perkin Elmer FTIR Frontier Serie 
99155 (Schwerzenbach, Switzerland) equipped with a PIKE TECHNOLOGIES GladiATRTM(OPUS 7.5 software). Preparative HPLCs were performed with a Merck Hitachi L-7000 (Chromaster system manager), which comprises a Pump L-7100 and a UV-Detector L-7400. A column Macherey-Nagel Nucleodur C18 HTec (5 $\mu \mathrm{m}$ particle size, $110 \AA ̊$ pore size, $250 \times 21 \mathrm{~mm}$, Oensingen, Switzerland) was used. Aqueous trifluoroacetic acid $0.1 \%$ solution and pure methanol were respectively used as solvents (A) and (B). Vitamin $\mathrm{B}_{12}$ and TCPP derivatives were purified using the following HPLC gradients: 0-5 $\min (75 \% \mathrm{~A}), 5-35 \mathrm{~min}(75 \% \mathrm{~A} \rightarrow 0 \% \mathrm{~A}), 35-45 \mathrm{~min}(100 \% \mathrm{~B})$ or $0-5 \min (50 \% \mathrm{~A}), 5-30 \mathrm{~min}(50 \% \mathrm{~A} \rightarrow$ $0 \% \mathrm{~A}), 30-45 \mathrm{~min}(100 \% \mathrm{~B})$, the flow rate set to $5 \mathrm{~mL} \mathrm{~min}^{-1}$ and the compounds detected at $320 \mathrm{~nm}$. For the analytical HPLCs, a Macherey-Nagel Nucleodur C18 HTec (5 um particle size, $110 \AA$ pore size, $250 \times 4.6 \mathrm{~mm}$, Oensingen, Switzerland) was used. Aqueous trifluoroacetic acid $0.1 \%$ solution and pure methanol were respectively used as solvents $(\mathrm{A})$ and $(\mathrm{B})$. The compounds were separated using the following gradient: $0-5 \mathrm{~min}(75 \% \mathrm{~A}), 5-35 \mathrm{~min}(75 \% \mathrm{~A} \rightarrow 0 \% \mathrm{~A}), 35-45 \mathrm{~min}(100 \% \mathrm{~B})$ or 0-5 min $(50 \% \mathrm{~A}), 5-30 \mathrm{~min}(50 \% \mathrm{~A} \rightarrow 0 \% \mathrm{~A}), 30-45 \mathrm{~min}(100 \% \mathrm{~B})$, the flow rate set to $0.5 \mathrm{~mL} \mathrm{~min}^{-1}$ and the compounds detected at $320 \mathrm{~nm}$. Scanning Electron Microscopy (SEM) pictures were recorded using a Tescan Mira3 LM FE SEM (TESCAN GmbH, Dortmund, Germany). Samples were coated with $4 \mathrm{~nm}$ to $10 \mathrm{~nm}$ platinum, depending on the analysis, and recorded at $10.0 \mathrm{kV}$ under high vacuum $6 \times 10^{-4} \mathrm{~Pa}$. Measurements of Inductively Coupled Plasma with Optical Emission Spectroscopy (ICP-OES) were performed with a Perkin Elmer Optima 7000 DV (Schwerzenbach, Switzerland). The zeta potential was measured with a DelsaMax PRO device from Beckmann Coulter (Nyon, Switzerland) using the Smoluchowski mode. Clean hydroxylated diatoms (OH-DEMs), aminated diatoms ( $\left.\mathrm{NH}_{2}-\mathrm{DEMs}\right)$, $\mathrm{B}_{12}$-TCPP-DEMs or $\mathrm{B}_{12}$-ZnTCPP-DEMs were diluted in a PBS buffer solution to $0.01 \mathrm{wt} \%$ and sonicated before proceeding with the measurement.

\subsection{Density Functional Theory (DFT) Calculations}

All computations were performed with the Gaussian 09 programs on the DALCO Cluster of the University of Fribourg. The procedure of minenkov et al. [50] was used, and different combinations of functional and basis sets were tried. Geometry optimizations were performed employing a solvent continuum dielectric model for water. The hybrid-GGA (GGA = generalized gradient approximation) functional M06 and B3LYP were used in combination with the standard LanL2DZ basis sets for the optimization of $\mathrm{B}_{12}-\mathrm{TCPP}$ and $\mathrm{B}_{12}-\mathrm{Mn}$, respectively. For the spin state of the molecules (singlet state in all cases), the default spin formalism was followed in the calculations, and default Gaussian 09 values were adopted for the numerical integration grids, self-consistent-field (SCF) and geometry optimization convergence criteria. Geometries were optimized without symmetry restrictions. The nature of the stationary points was checked by computing vibrational frequencies in order to verify true minima. No negative frequencies were observed for the reported values. The calculated molecular geometries were visualized using GaussView.

\subsection{Syntheses}

\subsubsection{5,10,15,20-Tetrakis (4-Carboxyphenyl) Porphyrin (TCPP)}

TCPP was synthetized via the monopyrrole tetramerization method originally described by Adler et al. and slightly modified [51,52]. First, $1.5 \mathrm{~g}$ of 4-carboxybenzaldehyde (10 mmol) was added to $50 \mathrm{~mL}$ acetic acid, stirred and heated to $80^{\circ} \mathrm{C}$ for better dissolution of the aldehyde. Afterward, distilled pyrrole $(0.7 \mathrm{~mL}, 10 \mathrm{mmol})$ was added, and the reaction mixture was brought to reflux and stirred for $2 \mathrm{~h}$. After the reaction mixture was allowed to cool to room temperature, the reaction flask was placed in the fridge to induce precipitation of the porphyrin. Vacuum filtration of the reaction mixture, washing the residue with DCM (5 times $50 \mathrm{~mL}$ ) and recrystallization permitted the isolation of a dark purple solid $(1.1 \mathrm{~g}, 1.4 \mathrm{mmol}, 55 \%$ yield), which was dried under vacuum in the oven. ${ }^{1} \mathrm{H} \mathrm{nmR}(400 \mathrm{MHz}, \mathrm{DMSO}-\mathrm{d} 6) \delta(\mathrm{ppm})=-2.93(\mathrm{~s}, 2 \mathrm{H}), 8.32-8.36$ (d, $\left.8 \mathrm{H}\right), 8.37-8.40(\mathrm{~d}, 8 \mathrm{H})$, 8.85 (s, 8 H) (ESI Figure S1), which was consistent with previous studies [53]; HR-ESI-MS (ESI+) $(\mathrm{m} / \mathrm{z})$ : 
$[\mathrm{M}+\mathrm{H}]^{+}=791.0$, calculated for $\mathrm{C}_{48} \mathrm{H}_{30} \mathrm{~N}_{4} \mathrm{O}_{8}=790.21$; UV-Vis (in $\mathrm{MeOH}, \lambda \max , \mathrm{nm}$ ): 415, 512, 546, $588.5,645$.

\subsubsection{Vitamin $B_{12}$ Derivative $B_{12}-1$}

Cyanocobalamin was modified by pegylation on the $5^{\prime}$-hydroxylic function of the ribose moiety by slight modification of published procedures [54,55]. Briefly, $100 \mathrm{mg}$ of reduced $\mathrm{B}_{12}(0.0739 \mathrm{mmol})$ was mixed with $75 \mathrm{mg}$ of CDT in $3 \mathrm{~mL}$ of DMSO and stirred overnight. The product was then precipitated in ethyl acetate $(150 \mathrm{~mL})$ and centrifuged for $10 \mathrm{~min}$ at $6000 \mathrm{rpm}$ in order to recover a red precipitate. The dried precipitate was resolubilized in $1 \mathrm{~mL}$ anhydrous DMF, and $100 \mu \mathrm{L}$ of 4,7,10-trioxa-1,13-tridecanediamine in $1 \mathrm{~mL}$ anhydrous DMF was added and stirred for $24 \mathrm{~h}$. The mixture was precipitated in 3:1 ether:ethyl acetate $(150 \mathrm{~mL})$ and centrifuged for $10 \mathrm{~min}$ at $6000 \mathrm{rpm}$ before being purified by preparative HPLC. The fraction corresponding to the pegylated $B_{12}\left(B_{12}-1\right)$ was evaporated under vacuum and further lyophilisated to recover a pure dried red powder.

\subsubsection{Vitamin $\mathrm{B}_{12}$ Derivative $\mathrm{B}_{12}$-TCPP}

In the dark and under a nitrogen atmosphere, to a solution of TCPP $\left(25.5 \mathrm{mg}, 3.23 \times 10^{-5} \mathrm{~mol}\right) \mathrm{in}$ $3 \mathrm{~mL}$ anhydrous DMF, EDC hydrochloride $\left(12.3 \mathrm{mg}, 6.45 \times 10^{-5} \mathrm{~mol}\right)$ and NHS $\left(7.4 \mathrm{mg}, 6.45 \times 10^{-5} \mathrm{~mol}\right)$ were added. After stirring for $1 \mathrm{~h}$ at room temperature, $\mathrm{B}_{12}-1\left(34.4 \mathrm{mg}, 2.15 \times 10^{-5} \mathrm{~mol}\right)$ in $1 \mathrm{~mL}$ anhydrous DMF and $20 \mu \mathrm{L}$ TEA were added and the reaction mixture was stirred for 3 days in the dark under argon atmosphere. Afterward, the product was precipitated in 3:1 ether:ethyl acetate $(150 \mathrm{~mL})$ and centrifuged for $10 \mathrm{~min}$ at $6000 \mathrm{rpm}$ before being purified by preparative HPLC $(7.7 \mathrm{mg}$, $3.23 \times 10^{-6} \mathrm{~mol}, 15 \%$ yield). ${ }^{1} \mathrm{H} \mathrm{nmR}(500 \mathrm{MHz}$, methanol-d4) $\delta(\mathrm{ppm})=0.42(\mathrm{~s}, 3 \mathrm{H}), 1.05(\mathrm{~s}, 3 \mathrm{H})$, $1.19(\mathrm{~d}, \mathrm{~J}=6.41 \mathrm{~Hz}, 4 \mathrm{H}), 1.26-1.37(\mathrm{~m}, 15 \mathrm{H}), 1.80(\mathrm{~s}, 3 \mathrm{H}), 2.22(\mathrm{~d}, \mathrm{~J}=9.31 \mathrm{~Hz}, 6 \mathrm{H}), 2.33(\mathrm{~d}, \mathrm{~J}=7.78 \mathrm{~Hz}, 2 \mathrm{H})$, 2.41-2.57 (m, $17 \mathrm{H}), 2.79(\mathrm{~m}, 1 \mathrm{H}), 3.02(\mathrm{~s}, 1 \mathrm{H}), 3.14(\mathrm{~m}, 1 \mathrm{H}), 3.56-3.62(\mathrm{~m}, 6 \mathrm{H}), 3.64-3.76(\mathrm{~m}, 14 \mathrm{H})$, 4.06-4.17 (m, $4 \mathrm{H}), 4.32(\mathrm{~m}, 1 \mathrm{H}), 4.47(\mathrm{~d}, \mathrm{~J}=9.46 \mathrm{~Hz}, 1 \mathrm{H}), 4.59(\mathrm{~d}, \mathrm{~J}=11.60 \mathrm{~Hz}, 1 \mathrm{H}), 5.91(\mathrm{~s}, 1 \mathrm{H})$, $6.18(\mathrm{~d}, \mathrm{~J}=2.75 \mathrm{~Hz}, 1 \mathrm{H}), 6.52(\mathrm{~s}, 1 \mathrm{H}), 7.08(\mathrm{~s}, 1 \mathrm{H}), 7.19(\mathrm{~s}, 1 \mathrm{H}), 8.26-8.29(\mathrm{~m}, 2 \mathrm{H}), 8.33(\mathrm{~d}, \mathrm{~J}=6.56 \mathrm{~Hz}$, $8 \mathrm{H}), 8.47$ (d, J = $8.24 \mathrm{~Hz}, 6 \mathrm{H}) 8.85$ (br. s., $8 \mathrm{H}$ ) (ESI Figure S2); MALDI-TOF: $m / z=2371.35$, calculated for $\mathrm{C}_{122} \mathrm{H}_{138} \mathrm{CoN}_{20} \mathrm{O}_{25} \mathrm{P}^{-}=2372.92$; UV-Vis (in $\mathrm{MeOH}, \lambda \max , \mathrm{nm}$ ): 360, 415, 512, 546, 588.5, 645.

\subsection{4. $\mathrm{B}_{12}-\mathrm{ZnTCPP}$}

To a solution of $\mathrm{B}_{12}$-TCPP ( $\left.3 \mathrm{mg}, 1.26 \times 10^{-6} \mathrm{~mol}\right)$ in $3 \mathrm{~mL} \mathrm{MeOH}, 0.5 \mathrm{mg} \mathrm{Zn}(\mathrm{OAc})_{2} \cdot 2 \mathrm{H}_{2} \mathrm{O}$ were added, and the reaction mixture was stirred under reflux for $1 \mathrm{~h}$. Afterward, the reaction mixture was allowed to cool to room temperature. Vacuum filtration and washing the residue several times with water allowed removing excess zinc and permitted the isolation of a brown-red solid that was dried under vacuum in the oven. UV-Vis (in MeOH, $\lambda \max , \mathrm{nm}$ ): 360, 423.5, 517, 560, 601.

\subsubsection{TCPP Derivative TCPP-1}

To a solution of TCPP $\left(30 \mathrm{mg}, 3.8 \times 10^{-5} \mathrm{~mol}\right)$ in $5 \mathrm{~mL}$ anhydrous DMF, EDC hydrochloride $\left(9.1 \mathrm{mg}, 4.75 \times 10^{-5} \mathrm{~mol}\right)$ and NHS $\left(5.5 \mathrm{mg}, 4.75 \times 10^{-5} \mathrm{~mol}\right)$ were added. After stirring for $2 \mathrm{~h}$ at room temperature, $10 \mu \mathrm{L}$ of 4,7,10-trioxa-1,13-tridecanediamine and TEA $(20 \mu \mathrm{L})$ were added and the reaction mixture was stirred for 3 days in the dark under argon atmosphere. The product was precipitated in 3:1 ether:ethyl acetate $(160 \mathrm{~mL})$ and centrifuged for $10 \mathrm{~min}$ at $6000 \mathrm{rpm}$ before being purified by preparative HPLC ( $8 \mathrm{mg}, 8.06-6 \mathrm{~mol}, 21 \%$ yield). ${ }^{1} \mathrm{H} \mathrm{nmR}(400 \mathrm{MHz}$, DMSO-d6) $\delta(\mathrm{ppm})=-2.88$ (br. s., $2 \mathrm{H}), 1.76-1.85(\mathrm{~m}, 2 \mathrm{H}), 1.92$ (quin, J = 6.63 Hz, $2 \mathrm{H}), 2.84-2.93(\mathrm{~m}, 2 \mathrm{H}), 3.52(\mathrm{t}, \mathrm{J}=6.05 \mathrm{~Hz}, 4 \mathrm{H})$, 3.54-3.57 (m, $2 \mathrm{H}), 3.58-3.62(\mathrm{~m}, 8 \mathrm{H}), 7.62$ (br. s., $2 \mathrm{H}), 8.24-8.47(\mathrm{~m}, 16 \mathrm{H}), 8.77(\mathrm{t}, \mathrm{J}=5.56 \mathrm{~Hz}, 1 \mathrm{H})$, $8.86(\mathrm{~s}, 8 \mathrm{H})\left(\right.$ ESI Figure S3); HR-ESI-MS (ESI+) $(\mathrm{m} / \mathrm{z})$ : $[\mathrm{M}+\mathrm{H}]^{+}=993.3,[\mathrm{M}+2 \mathrm{H}]^{2+} / 2=497$, calculated for $\mathrm{C}_{58} \mathrm{H}_{52} \mathrm{~N}_{6} \mathrm{O}_{10}=993.09$; UV-Vis (in $\mathrm{MeOH}, \lambda \max , \mathrm{nm}$ ): 415, 512, 546, 588.5, 645. 


\subsubsection{ZnTCPP-1}

To a solution of $10 \mathrm{mg} \mathrm{TCPP}\left(1.0 \times 10^{-5} \mathrm{~mol}\right)$ in $5 \mathrm{~mL} \mathrm{DMF}, 2.65 \mathrm{mg} \mathrm{Zn}(\mathrm{OAc})_{2} \cdot 2 \mathrm{H}_{2} \mathrm{O}\left(1.2 \times 10^{-5} \mathrm{~mol}\right)$ were added, and the reaction mixture was stirred under reflux for $2 \mathrm{~h}$. Afterward, the reaction mixture was allowed to cool to room temperature. Vacuum filtration and washing the residue several times with water allowed removing excess zinc and permitted the isolation of a dark green solid, which was dried under vacuum in the oven (10 mg, $9.47 \times 10^{-6} \mathrm{~mol}, 94.7 \%$ yield). UV-Vis (in $\mathrm{MeOH}, \lambda \max , \mathrm{nm}$ ): $423.5,560,601$.

\subsection{7. fac-[Mn(I)Br(CO) $)_{3}(4,4-$ carboxyl-2,2-bipyridin)] (Mn)}

The manganese(I) photoCORM complex was synthetized by slight modification of a published procedure [56]. Bromopentacarbonylmanganese(I) $(150 \mathrm{mg}, 0.55 \mathrm{mmol}, 1$ equivalent with 1.1 equivalent of the 2,2'-Bipyridine-4,4'-dicarboxylic acid $(148 \mathrm{mg}, 0.61 \mathrm{mmol})$ was stirred in THF $(20 \mathrm{~mL})$ under dark conditions overnight. Afterward, the mixture was filtered and the supernatant containing the complex (Mn) was dried under vacuum. Mn was then purified via HPLC before being evaporated to dryness in a lyophilizer. An orange-yellow solid was recovered. Yield $67.9 \mathrm{mg}(26 \%)$. UV/Vis spectrum in methanol solution: $\lambda \max =410$ (ESI Figure S12); FTIR (ATR, $\mathrm{cm}^{-1}$ ): $v_{\mathrm{C} \equiv \mathrm{O}}=2026,1943,1901,1733$ (ESI Figure S9). ESI-MS $\left(\right.$ pos $^{+}$): $[\mathrm{M}-\mathrm{Br}]^{+}=383.01$, calculated for $\mathrm{C}_{15} \mathrm{H}_{8} \mathrm{MnN}_{2} \mathrm{O}_{7}=382.97$. All other analytical data are in agreement with what was reported previously [56].

\subsubsection{Vitamin $\mathrm{B}_{12}$ Derivative $\mathrm{B}_{12}-\mathrm{Mn}$}

Cyanocobalamin was modified by pegylation on the hydroxylic function of the ribose part $\left(5^{\prime}-\mathrm{OH}\right)$ of the molecule as previously described $[25,57]$. The pegylated $\mathrm{B}_{12}$ was then reacted with the manganese complex $\mathrm{Mn}$ to give the $\mathrm{B}_{12}-\mathrm{Mn}$. For this purpose, $1.6 \mathrm{mg}(0.0035 \mathrm{mmol}, 1.5$ equivalent $)$ of Mn were activated in MES buffer pH 5.5 with $46 \mu \mathrm{L}$ EDC during $30 \mathrm{~min}$ in the dark before $17 \mathrm{mg}$ of NHS were added for another $30 \mathrm{~min}$ and finally $3.7 \mathrm{mg}(0.0023 \mathrm{mmol}, 1.0$ equivalent $)$ of pegylated $\mathrm{B}_{12}$ was poured dropwise in $1 \mathrm{~mL}$ MES buffer $\mathrm{pH}$ 5.5. For the next $5 \mathrm{~h}, 15 \mathrm{mg}$ of EDC were added each hour. Two hours after the last EDC addition, $50 \mu \mathrm{L}$ of TEAwas added to the mixture that was allowed to react overnight in the dark. The crude was finally purified by preparative HPLC. Each manipulation was done in diminished light due to the photo-sensitivity of Mn. Yield $3.7 \mathrm{mg}$ (79\%). ${ }^{1} \mathrm{H} \mathrm{nmR}(400 \mathrm{MHz}, \mathrm{MeOD}-[\mathrm{d} 4]): \delta=9.11(\mathrm{t}, \mathrm{J}=5.5 \mathrm{~Hz}, 2 \mathrm{H}), 8.88(\mathrm{~d}, \mathrm{~J}=7.4 \mathrm{~Hz}, 2 \mathrm{H})$, $8.16(\mathrm{~d}, \mathrm{~J}=4.3 \mathrm{~Hz}, 2 \mathrm{H}), 7.79(\mathrm{t}, \mathrm{J}=5.64 \mathrm{~Hz}, 1 \mathrm{H}) *, 7.23(\mathrm{~s}, 1 \mathrm{H}), 6.98(\mathrm{~s}, 1 \mathrm{H}), 6.42(\mathrm{~s}, 1 \mathrm{H}), 6.19(\mathrm{~d}, \mathrm{~J}=$ $2.5 \mathrm{~Hz}, 1 \mathrm{H}), 6.02(\mathrm{~s}, 1 \mathrm{H}), 4.77-4.72(\mathrm{~m}, 2 \mathrm{H}), 4.58(\mathrm{~d}, \mathrm{~J}=10.0 \mathrm{~Hz}, 1 \mathrm{H}), 4.22-4.16(\mathrm{~m}, 3 \mathrm{H}), 3.87(\mathrm{q}, \mathrm{J}=$ $5.33 \mathrm{~Hz}, 1 \mathrm{H}), 3.63-3.60(\mathrm{~m}, 10 \mathrm{H}), 3.55(\mathrm{t}, \mathrm{J}=5.47 \mathrm{~Hz}, 2 \mathrm{H}), 3,51(\mathrm{q}, \mathrm{J}=1.65 \mathrm{~Hz}, 1 \mathrm{H}), 3.49(\mathrm{~s}, 1 \mathrm{H})$, $3.46(\mathrm{~s}, 1 \mathrm{H}), 3.38(\mathrm{~s}, 1 \mathrm{H}), 3.30-3.12(\mathrm{~m}, 8 \mathrm{H}), 2.93-2.86(\mathrm{~m}, 1 \mathrm{H}), 2.80-2.73(\mathrm{~m}, 2 \mathrm{H}), 2.64-2.54(\mathrm{~m}, 4 \mathrm{H})$, 2.53-2.39 (m, $14 \mathrm{H}), 2.28(\mathrm{~s}, 6 \mathrm{H}), 2.08-1.93(\mathrm{~m}, 8 \mathrm{H}), 1.91-1.74(\mathrm{~m}, 12 \mathrm{H}), 1.74-1.65(\mathrm{~m}, 2 \mathrm{H}), 1.55(\mathrm{~s}, 1 \mathrm{H})$, $1.52(\mathrm{~s}, 1 \mathrm{H}), 1.46(\mathrm{~s}, 3 \mathrm{H}), 1.53(\mathrm{~d}, 1 \mathrm{H}), 1.34(\mathrm{~s}, 3 \mathrm{H}), 1.26(\mathrm{~d}, \mathrm{~J}=6.3 \mathrm{~Hz}, 3 \mathrm{H}), 1.22(\mathrm{~s}, 3 \mathrm{H}), 1.05(\mathrm{~s}, 3 \mathrm{H})$, 1.01-0.88 (m, $2 \mathrm{H}), 0.40(\mathrm{~s}, 3 \mathrm{H}) \mathrm{ppm}$. * amide, disappear with proton exchange (ESI Figure S4); UV/Vis spectrum in methanol solution: $\lambda \max =361,415,519,551$ (ESI Figure S13); FTIR $\left(\right.$ ATR, $\left.\mathrm{cm}^{-1}\right): v_{\mathrm{C} \equiv \mathrm{O}}=$ 2043, 1961, 1944 (ESI Figure S10).

\subsection{DEMs Functionalizations}

The isolation, purification and surface activation of DEMs were done as previously described by Delasoie et al. [25]. The aminated DEMs surface was generated by APTES condensation.

\subsection{1. $\mathrm{B}_{12}$-TCPP-DEMs}

To a solution of $\mathrm{B}_{12}$-TCPP $\left(2.5 \mathrm{mg}, 1.05 \times 10^{-6} \mathrm{~mol}\right)$ in $1 \mathrm{~mL}$ anhydrous DMF, EDC hydrochloride $\left(0.4 \mathrm{mg}, 2.1 \times 10^{-6} \mathrm{~mol}\right)$ and NHS $\left(0.26 \mathrm{mg}, 2.1 \times 10^{-6} \mathrm{~mol}\right)$ were added. After stirring for $1 \mathrm{~h}$ in the dark at room temperature, $\approx 10 \mathrm{mg}$ of aminated DEMs in $0.2 \mathrm{~mL}$ anhydrous DMF and TEA $(20 \mu \mathrm{L})$ were added and the reaction mixture was stirred for 3 days in the dark at room temperature. 
Afterward, the functionalized DEMs were separated by centrifugation and washed several times with $\mathrm{MeOH}$ and water, yielding a slightly reddish powder. The material was characterized by UV solid-state (Figure 2) and zeta potential.

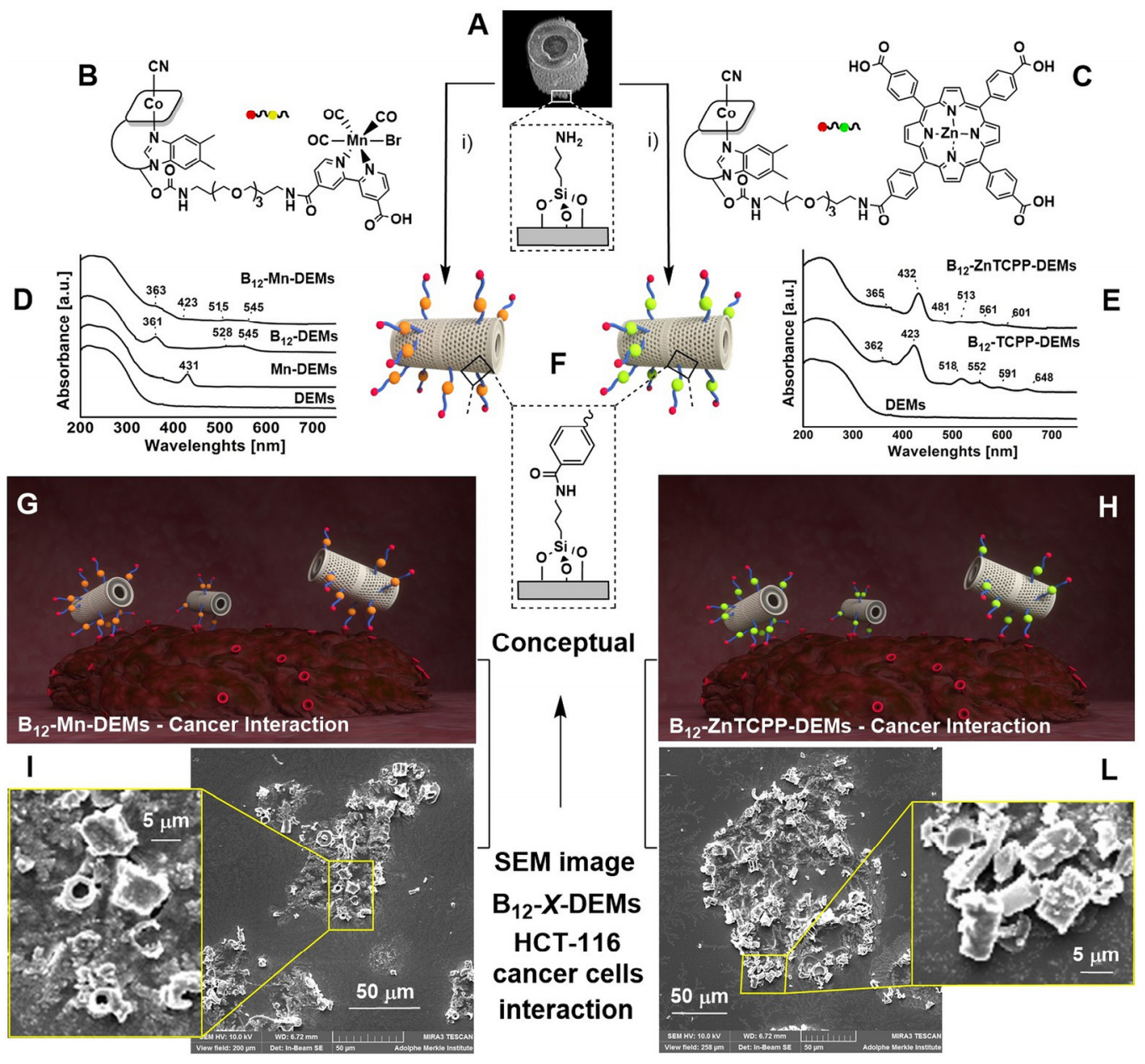

Figure 2. (A) SEM image of one raw diatom piece. (B,C) Structures of $B_{12}-\mathrm{Mn}$ and $B_{12}-Z n T C P P$, respectively. (D,E) Solid-state UV-Vis spectra of different functionalized DEMs. (F) Conceptual drawing of functionalized $\mathrm{B}_{12}$-X-DEMs $(X=\mathrm{Mn}$ or $\mathrm{ZnTCPP})$ and detail of molecular bonding at the surface of microalgae. $(\mathbf{G}, \mathbf{H})$ Conceptual images of $\mathrm{B}_{12}$-Mn-DEMs and $\mathrm{B}_{12}$-ZnTCPP-DEMs interacting with a tumor mass. (I,L) SEM images of $B_{12}$ derivatized DEMs attached to HCT-116 colorectal cancer cells and representative magnification.

\subsection{2. $\mathrm{B}_{12}$-ZnTCPP-DEMs}

$\mathrm{B}_{12}$-TCPP-DEMs in $\mathrm{MeOH}$ were stirred under reflux in the presence of $\mathrm{Zn}(\mathrm{OAc})_{2} \cdot 2 \mathrm{H}_{2} \mathrm{O}(1 \mathrm{mg})$ for $1 \mathrm{~h}$. Afterward, the functionalized DEMs were separated by centrifugation and washed several times with $\mathrm{MeOH}$ and water to yield a slightly brownish powder. The material was characterized by UV solid-state (Figure 2) and zeta potential.

\subsubsection{Mn-DEMs}

In order to functionalize the aminated DEMs with $\mathrm{Mn}, 0.5 \mathrm{mg}$ of $\mathrm{Mn}$ were dissolved in $1 \mathrm{~mL}$ DMF with $1 \mathrm{mg}$ of EDC under diminished light and stirred for $30 \mathrm{~min}$. Then, $1 \mathrm{mg}$ of NHS was added and let react for the next $30 \mathrm{~min}$. After direct addition of ca. $10 \mathrm{mg}$ of aminated DEMs and $20 \mu \mathrm{L} \mathrm{TEA}$, the mixture was reacted overnight at RT in the dark. The mixture was then centrifuged 
and the supernatant discarded, and this was repeated with $10 \mathrm{~mL}$ DMF and $10 \mathrm{~mL}$ methanol thrice. The sample was finally dried under vacuum. The recovered powder was denoted as Mn-DEMs.

\subsection{4. $\mathrm{B}_{12}$-Mn-DEMs}

To achieve the functionalization of aminated DEMs with $\mathrm{B}_{12}-\mathrm{Mn}$, typically $0.8 \mathrm{mg}$ of $\mathrm{B}_{12}-\mathrm{Mn}$ was added to $0.15 \mathrm{mg}$ of EDC chloride and $0.10 \mathrm{mg}$ of NHS in $1 \mathrm{~mL}$ DMF for $1 \mathrm{~h}$ diminished light. Then, $2 \mathrm{mg}$ of DEMs in $0.5 \mathrm{~mL}$ DMF was added to the mixture. Twenty microliters of TEA were added directly after. The mixture was reacted at RT in the dark overnight. The mixture was then centrifuged and the supernatant discarded. The recovered powder was washed with $20 \mathrm{~mL}$ DMF and with $20 \mathrm{~mL}$ methanol thrice and finally dried under vacuum overnight. The recovered powder was denoted as $\mathrm{B}_{12}$-Mn-DEMs.

\subsection{Photodynamic Measurements}

For fluorescence quantum yield and lifetime measurements, diluted solutions of ZnTCPP, ZnTCPP-1 and $\mathrm{B}_{12}$-ZnTCPP in DMSO were prepared in $1 \mathrm{~cm}$ quartz cuvettes. Fluorescence spectra were recorded with an FS5 Spectrofluorometer from Edinburgh Instruments (General Microtechnology \& Photonics, Renens, Switzerland). Fluorescence quantum yields were measured with the same instrument equipped with an integrating sphere. The fluorescence lifetime of the samples was determined with a time-correlated single-photon-counting (TCSPC) LifeSpec II instrument from Edinburgh Instruments General Microtechnology \& Photonics, Renens, Switzerland) equipped with an EPL-405 picosecond pulsed diode laser from Edinburgh Photonics (General Microtechnology \& Photonics, Renens, Switzerland). The detection was set to emitted photons at a wavelength of $660 \mathrm{~nm}$. Both quantum yields and lifetime data were elaborated with Fluoracle@software (2015) provided by Edinburgh Instruments.

Singlet oxygen quantum yield. $\left(\Phi_{\Delta}\right)$ were determined via assessment of light absorption decrease based on the oxidation of 9,10-dimethylanthracene (DMA) generating an endoperoxide in a [4 + 2]-reaction. Tetraphenylporphyrin (TPP) in DMSO $\left(\Phi_{\Delta}^{R}=0.52\right)$ was used as reference to calculate $\Phi_{\Delta}$ for the PS [58]. A DMA solution $\left(1.45 \times 10^{-4} \mathrm{M}\right.$ in DMSO) was mixed with the PS in a $1 \mathrm{~cm}$ quartz cuvette and bubbled with oxygen for $5 \mathrm{~min}$. The absorbance of the reaction mixture was taken at $401 \mathrm{~nm}$. The cuvette was irradiated by a $100 \mathrm{~W}$ LED-light at $420 \mathrm{~nm}$ (LUMOS 43 from Atlas Photonics), and the decrease in the absorbance of DMA at $401 \mathrm{~nm}$ was followed. The measurements were done in triplicate. The kinetics of DMA photo-oxidation permits one to calculate the singlet oxygen generation of the PS. The following equation is used:

$$
\Phi_{\Delta}^{S}=\Phi_{\Delta}^{R} \frac{K^{S} I^{R}}{K^{R} I^{S}}
$$

where $K^{R}$ and $K^{S}$ are the slopes of the kinetic plot of the difference in absorbance vs. irradiation time of DMA photo-oxidized by the reference and sample, respectively; $I^{R}$ and $I^{S}$ the total light intensities absorbed by the reference and sample and $\Phi_{\Delta}^{S}$ the singlet oxygen quantum yield of the sample. Light intensities were calculated according to the following equation:

$$
I=I_{0}\left(1-10^{-A(\lambda=420 \mathrm{~nm})}\right)
$$

where $I$ is the absorbed light intensity from the sample, $I_{0}$ the light intensity from the light source and $A(\lambda=420 \mathrm{~nm})$ the absorbance of the photosensitizer at the excitation wavelength. 


\subsection{Kinetic and Equivalent CO Released by Photoirradiation}

For both $\mathrm{Mn}$ and $\mathrm{B}_{12}-\mathrm{Mn}$ complexes, the kinetic of $\mathrm{CO}$ release was evaluated by monitoring the spectral changes at a specific wavelength (410 and $365 \mathrm{~nm}$ respectively) by UV/Vis spectroscopy. For this purpose, the complexes were firstly dissolved in DMSO (1\% v/v, final concentration) before being diluted in $0.1 \mathrm{M}$ PBS. Samples were irradiated with a $420 \mathrm{~nm}$ light. Then, the equivalent of $\mathrm{CO}$ release was evaluated under the conditions of myoglobin assay for all complexes. The solutions Mn $(15 \mu \mathrm{M})$ and $\mathrm{B}_{12}-\mathrm{Mn}(10 \mu \mathrm{M})$, measured in $0.1 \mathrm{M}$ PBS buffer at $\mathrm{pH} 7.4,10 \mathrm{mM}$ dithionite, with 3 equivalent of myoglobin (respectively 45 and $30 \mu \mathrm{M}$ ), under argon, were irradiated with a $420 \mathrm{~nm}$ light. The stability of each compound in the presence of dithionite was evaluated prior to each experiment, and none of them showed spontaneous $\mathrm{CO}$ release. The concentration of Myoglobin- $\mathrm{CO}$ complex $\mathrm{c}(\mathrm{Mb}-\mathrm{CO})$ formed through time due to $\mathrm{CO}$ release from the photoCORMs upon irradiation at $420 \mathrm{~nm}$ was monitored, and the CO release equivalent was calculated as described by Atkin et al. [59]. Due to its poor solubility, Mn was previously dissolved in DMSO (1\% v/v, final concentration).

\subsection{Resistance of $B_{12}-X-D E M s$ in Simulated Digestive Fluids}

The test was performed in simulated gastric fluid (SGF). For this purpose, ca. $4 \mathrm{mg}$ of each $\mathrm{B}_{12}$-X-DEMs sample was digested in SGF $(6 \mathrm{~mL})$ for $2 \mathrm{~h}$ before the solid residue and the supernatant were recovered. The supernatant was diluted to $10 \mathrm{~mL}$ with $\mathrm{HNO}_{3} \%(v / v)$. The solid fraction was digested for a second time in $2 \mathrm{~mL}$ piranha solution $\left(\mathrm{H}_{2} \mathrm{SO}_{4}: \mathrm{H}_{2} \mathrm{O}_{2}\right.$ 7:1) overnight before being diluted to $10 \mathrm{~mL}$ with deionized water. All the samples were analyzed by ICP-OES (Co monitoring). The result was calculated as a mass ratio of the $\mathrm{B}_{12}$ equivalent compared to the total amount of sample.

\subsection{Drug Loading and Release from DEMs}

Around $2 \mathrm{mg}$ of the rhenium complexes used as model drugs (1 or $\mathbf{2}$, vide infra) was weighed and dissolved in $20 \mu \mathrm{L}$ of DMSO, and then $10 \mu \mathrm{L}$ of this solution of $100 \mathrm{mg} / \mathrm{mL}$ was diluted (100 fold) to $1000 \mu \mathrm{L}$ with aqueous buffer PBS pH 7.4 (1\% v/v, DMSO), giving the first standard solution $\left(\mathrm{S} 1,1.0 \mathrm{mg} \mathrm{mL}^{-1}\right)$. Dilutions of S1 in PBS pH 7.4 (1\% v/v, DMSO) gave the standards used for the calibration curves (5 standards, $\mathrm{R}^{2}>0.9$ ). The standards and samples were analyzed by UV-Vis spectroscopy. For each measurement, the sample was quickly vortexed before being transferred for UV-Vis measurement. The drug loadings (DL) were performed by weighing around $10 \mathrm{mg}$ of the drug and the same amount of DEMs in an Eppendorf. Afterward, $1 \mathrm{~mL}$ of acetone was added to obtain a $10 \mathrm{mg} \mathrm{mL}^{-1}$ drug solution. The samples were shaken on the plate for $48 \mathrm{~h}$. The mixtures were then centrifuged and the supernatant removed. A quick wash was performed by adding $500 \mu \mathrm{L}$ of acetone, centrifuging $5 \mathrm{~s}$ and removing supernatant. The samples were then evaporated under argon to dryness. Drug release experiments were performed by adding $1000 \mu \mathrm{L}$ of PBS pH 7.4 (1\% DMSO) to the drug-loaded DEMs samples. Samples of $100 \mu \mathrm{L}$ were taken at each time point and replaced with fresh buffer. The concentrations of these samples were evaluated by UV-VIS spectroscopy by monitoring the absorption of the complexes at specific wavelengths. The values for the cumulative drug release in percentage were calculated from the linear regressions previously established. The graphs were plotted using Origin 7.5. The DL were calculated as the mass percentage (wt $\%$ ) of drug over the sum of drug and DEMs.

\subsection{Cytotoxicity Assessment}

Rhenium anticancer complexes 1 and $\mathbf{2}$ were freshly dissolved first in DMSO and then in RPMI 1640 medium (Merck, Munich, Germany), while the other analyzed compounds were immediately dissolved in RPMI 1640 medium and used for bioactivity assessments. In vitro cytotoxicity in terms of antiproliferative effects was determined by (3-(4,5-dimethylthiazol-2-yl)-2,5-diphenyltetrazolium bromide (MTT) assay [60] on colorectal cancer HCT116 cell line, obtained from American Type Culture Collection (ATCC). The cells, cultured in the complete RPMI 1640 medium as a monolayer $\left(1 \times 10^{4}\right.$ cells 
per well), were incubated with test compounds for $48 \mathrm{~h}$ in humidified atmosphere of $95 \%$ air and $5 \%$ $\mathrm{CO}_{2}$ at $37^{\circ} \mathrm{C}$, and the MTT assay was carried out two times in four replicates. The extent of MTT reduction was measured spectrometrically at $540.0 \mathrm{~nm}$ using Tecan Infinite 200 Pro multiplate reader (Tecan Group Ltd., Männedorf, Switzerland), and the cell survival was expressed as a percentage of the control arbitrarily set to $100 \%$. Cytotoxicity was expressed as the concentration of the compound inhibiting cell growth by $50 \%\left(\mathrm{IC}_{50}\right)$ in comparison to untreated control. For the photoactivation experiment, Osram L30W/840 cool white light Lumilux (Munich, Germany) has been used two times for $10 \mathrm{~min}$, immediately upon the addition of compounds to the cells and $1 \mathrm{~h}$ after.

\section{Results and Discussion}

\subsection{Synthesis and Characterization of Surface Coating molecules}

Vitamin $\mathrm{B}_{12}$ (tumor-targeting agent) surface-coated molecules bearing either a (2,2'-bipyridine)-3,4'-dicarboxylic acid manganese tricarbonyl complex (photoCORM, $\mathrm{B}_{12}-\mathrm{Mn}$ ) or a zinc of 5, 10, 15, 20-tetrakis(4-carboxyphenyl)porphyrin molecule (PDT agent, $\mathrm{B}_{12}$-ZnTCPP) were prepared according to the synthetic procedure illustrated in Scheme 1. Vitamin $\mathrm{B}_{12}$ (represented by a simplified structure) was first modified with an aminated PEG-chain on the $5^{\prime}-\mathrm{OH}$ ribose moiety and then reacted directly with the manganese complex (Mn, giving $\mathrm{B}_{12}-\mathrm{Mn}$, path $\mathrm{A}$ in Scheme 1$)$ or with 5,10,15,20-tetrakis(4-carboxyphenyl)porphyrin (TCPP) respectively (path B in Scheme 1). The latter was finally metalated with zinc(II) acetate, giving $\mathrm{B}_{12}$-ZnTCPP. Alternatively, $\mathrm{B}_{12}$-ZnTCPP could be prepared by PEGylation of TCPP followed by metalation and coupling to vitamin $\mathrm{B}_{12}$ (path $\mathrm{C}$ in Scheme 1). We noted that the length of the selected PEG-chain allows vitamin $B_{12}$ derivatives to be still recognized by the transcobalamin receptors (TC(II) and TC(II)-R), leading to increased adherence towards cancer cells $[25,61,62]$. Density functional theory (DFT) calculations of $\mathrm{B}_{12}-\mathrm{Mn}$ and $\mathrm{B}_{12}$-TCPP performed in water (polarizable continuum model, vide infra, Figure 3) indicate a distance of ca. $18 \AA$ between the molecular units. Thus, the PEG chain does not only act as a linker but also provides a certain degree of freedom to the system. Indeed, we expected this distance to minimize steric hindrance in the final composite materials, allowing the different components to play their role with minimal interferences [63]. Once grafted onto the surface of diatom microalgae, this arrangement facilitates the role of $\mathrm{B}_{12}$ as the tumor-targeting agent [25]. At the same time, photoactivation of the surface allows for $\mathrm{CO}$ release from $\mathrm{B}_{12}-\mathrm{Mn}$ or ${ }^{1} \mathrm{O}_{2}$ generation from $\mathrm{B}_{12}$-ZnTCPP respectively. Both surface-coating derivatives were characterized by standard techniques. ${ }^{1} \mathrm{H}-\mathrm{NMR}$, visible spectroscopy and MS data are fully consistent with the proposed molecular structures of $\mathrm{B}_{12}-\mathrm{Mn}$ and $\mathrm{B}_{12}$-ZnTCPP. Particularly revealing were the ${ }^{1} \mathrm{H}-\mathrm{NMR}$ spectra of the molecules (ESI Figures S1-S4). As expected, the homotopicity of the aromatic protons of the (2,2'-bipyridine)-3,4'-dicarboxylic acid and TCPP of $\mathrm{B}_{12}-\mathrm{Mn}$ and $\mathrm{B}_{12}-\mathrm{ZnTCPP}$, respectively, was lost upon coupling to $\mathrm{B}_{12}-1$ (i.e., PEGylated vitamin $B_{12}$, see Scheme 1). In the case of $B_{12}$-ZnTCPP, e.g., the symmetric 1:1 doublets of TCPP split into three doubles of relative intensity of 4:3:1; the latter being assigned to the 4-carboxyphenyl protons in ortho-position to the newly formed amide bond (ESI Figure S1). Metalation of $B_{12}$-TCPP was confirmed by UV-Vis spectroscopy. Indeed, the Soret band of the porphyrin undergoes a bathochromic shift from 415 to $423 \mathrm{~nm}$ upon reaction with $\mathrm{Zn}(\mathrm{OAc})_{2} \cdot 2 \cdot \mathrm{H}_{2} \mathrm{O}$ (Figure 3). Moreover, upon metalation, the degeneracy in the porphyrin orbital causes the coalescence of the four TCPP $Q$-bands $(512,546$, 588 and $645 \mathrm{~nm}$ ) into two $Q$-bands in $B_{12}$-ZnTCPP (560 and $601 \mathrm{~nm}$ ), as previously described $[64,65]$. The peaks at $360 \mathrm{~nm}$ and $517 \mathrm{~nm}$ were respectively attributed to the $\alpha$-band and $\beta$-band of vitamin $B_{12}$ (Figure 3). 


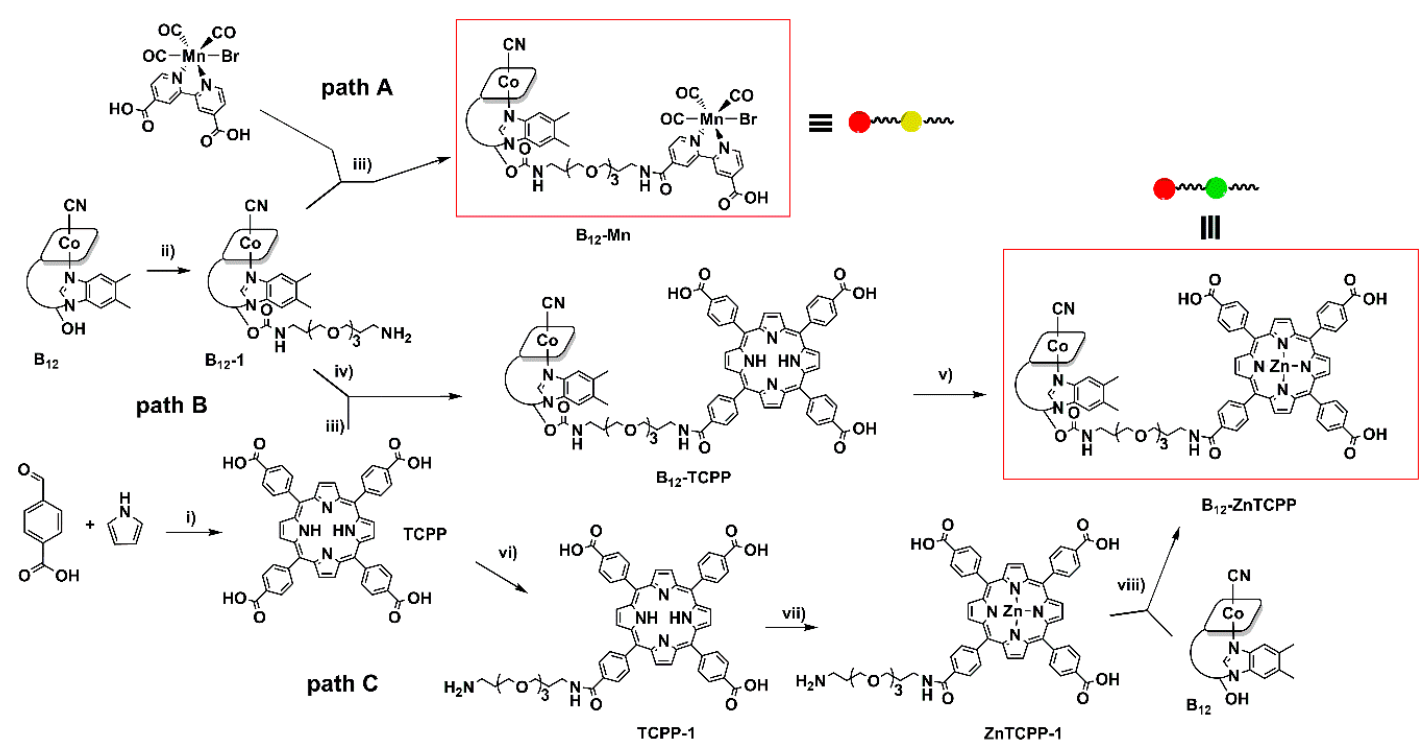

Scheme 1. Reaction steps for the synthesis of $B_{12}-M n$ and $B_{12}$-ZnTCPP. Reagents and conditions: (i) $2 \mathrm{~h}$, acetic acid under reflux; (ii) CDT, $24 \mathrm{~h}$, DMSO, then PEG, $24 \mathrm{~h}$, anhydrous DMF; (iii) EDC/NHS, $1 \mathrm{~h}$, anhydrous DMF, diminished light, RT; (iv) $72 \mathrm{~h}$, anhydrous DMF, RT; (v) $\mathrm{Zn}(\mathrm{OAc})_{2} \cdot 2 \cdot \mathrm{H}_{2} \mathrm{O}, 1 \mathrm{~h}, \mathrm{MeOH}$ under reflux; (vi) EDC/NHS, $2 \mathrm{~h}$, anhydrous DMF, RT; (vii) $\mathrm{Zn}(\mathrm{OAc})_{2} \cdot 2 \cdot \mathrm{H}_{2} \mathrm{O}, 1 \mathrm{~h}, \mathrm{MeOH}$ under reflux; (viii) CDT, DMSO, $12 \mathrm{~h} /$ anhydrous DMF, $24 \mathrm{~h}$.
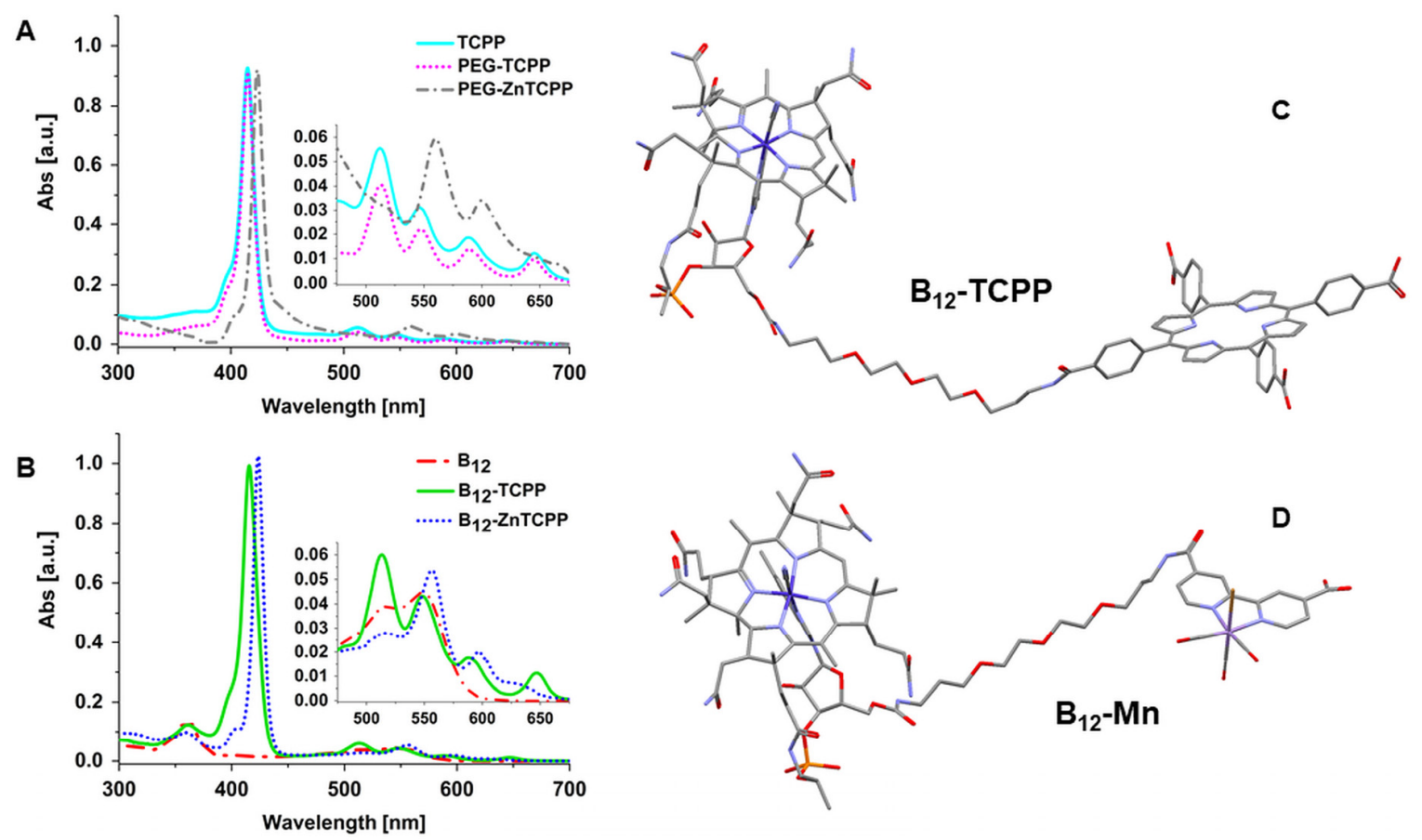

Figure 3. (A,B) represent the UV-Vis absorption spectra of TCPP, PEG-TCPP, PEG-ZnTCPP and $\mathrm{B}_{12}, \mathrm{~B}_{12}-\mathrm{TCPP}, \mathrm{B}_{12}-\mathrm{ZnTCPP}$, respectively; (C,D) show optimized structures of $\mathrm{B}_{12}-\mathrm{TCPP}$ and $\mathrm{B}_{12}-\mathrm{Mn}$, respectively, calculated in silico by Density functional theory (DFT) (polarizable continuum model with water as solvent). $\mathrm{C}$-atoms are grey, $\mathrm{N}$-atoms blue, $\mathrm{O}$-atoms red, $\mathrm{P}$ is orange and Co dark blue. $\mathrm{H}$-atoms are omitted for clarity.

\section{2. ${ }^{1} \mathrm{O}_{2}$ Generation and $\mathrm{CO}$ Release of Surface Coating molecules}

Fluorescence quantum yield $\left(\Phi_{f l}\right)$, lifetime $\left(\tau_{f}\right)$ and singlet oxygen $\left({ }^{1} \mathrm{O}_{2}\right)$ quantum yield $\left(\Phi_{\Delta}\right)$ were assessed for PEG-ZnTCPP and $B_{12}$-ZnTCPP in DMSO (Table 1). Fluorescence spectra of PEG-ZnTCPP 
and $\mathrm{B}_{12}$-ZnTCPP in DMSO show emission bands around 612 and $666 \mathrm{~nm}$ (ESI Figure S7), and the fluorescence quantum yields and lifetimes are similar for the two species. The results are consistent with values reported in the literature for comparable porphyrin analogs and support the hypothesis that the structural change at the periphery of the porphyrin does not drastically affect $\Phi_{f l}$ and $\tau_{f}$ since the fluorescence phenomenon arises from the inner $\pi$-electron system on the macrocycle [65-67]. Nevertheless, it is known that introducing electron-donating or -withdrawing groups onto porphyrin center will slightly influence the fluorescence properties [68]. Longer fluorescence lifetime and improved inter-system crossing positively influence the singlet oxygen quantum yield, but the same is affected by many other parameters such as solubility or the tendency of the fluorophore to form aggregates. However, $\Phi_{\Delta}$ does not correlate to the fluorescence lifetime and quantum yield improvement. Porphyrins can easily aggregate in solution, thereby lowering their efficiency in energy transfer, with ${ }^{3} \mathrm{O}_{2}$ resulting in lower ${ }^{1} \mathrm{O}_{2} \Phi_{\Delta}[69,70]$. The solubility and aggregation propensity of the zinc(II) porphyrin are substantially modified by introducing a hydrophilic PEG chain or a large and highly water-soluble structure like vitamin $B_{12}$. The coupling of vitamin $B_{12}$ to ZnTCPP slightly increases the singlet oxygen quantum yield by $15 \%$. Indeed, vitamin $B_{12}$ covalently linked to the porphyrin enhances the solubility of the structure and lowers its tendency to aggregate, thereby leading to an efficient generation of ${ }^{1} \mathrm{O}_{2}$ singlet oxygen. $\mathrm{B}_{12}$-ZnTCPP is stable to light. We observed no decomposition of the molecule under irradiation, suggesting the great potential of $B_{12}-Z n T C P P$ in PDT. Pseudo-half-life and equivalents of $\mathrm{CO}$ released were measured for $\mathrm{B}_{12}-\mathrm{Mn}$ and its constituent photoCORM complex (Mn) [71] according to the method described by Atkin et al. (Table 1) [59]. To this end, changes in the UV-Vis spectrum at 410 and $365 \mathrm{~nm}$ were monitored as a function of irradiation time for $\mathrm{Mn}$ and $\mathrm{B}_{12}-\mathrm{Mn}$, respectively (ESI Figures S18-S21). The stabilities of both complexes were demonstrated by the absence of spontaneous $\mathrm{CO}$ releases in the dark in the presence of sodium dithionite. Both molecules, upon light irradiation, released ca. one equivalent of $\mathrm{CO}$ (ESI Figures S16 and S17).

Table 1. Fluorescence quantum yield $\left(\Phi_{f l}\right)$, lifetime $(\tau f)$ and singlet oxygen quantum yield $\left(\Phi_{\Delta}\right)$ of the porphyrin complexes in DMSO. Photo-induced CO-release kinetics of the manganese complexes in PBS buffer pH 7.4.

\begin{tabular}{cccc}
\hline Molecule & $\boldsymbol{\Phi}_{f l}$ & $\boldsymbol{\tau}_{\mathbf{f}} \mathbf{\pm 0 . 1}$ [ns] & $\boldsymbol{\Phi}_{\boldsymbol{\Delta}}$ \\
\hline ZnTCPP & 0.009 & 4.7 & $0.77 \pm 0.01$ \\
\hline PEG-ZnTCPP & 0.046 & 8.6 & $0.66 \pm 0.10$ \\
\hline $\mathrm{B}_{12}-Z n T C P P$ & 0.035 & 5.7 & $0.90 \pm 0.03$ \\
\hline & $\mathbf{t}_{\mathbf{1} / \mathbf{2}}[\mathbf{s}]^{\mathbf{a}}$ & ${\text { Equivalent of CO } \text { released }^{\mathbf{b}}}^{\mathbf{2}}$ & \multicolumn{2}{c}{$1.3 \pm 0.1$} \\
\hline $\mathrm{Mn}^{\mathrm{c}}$ & $1.6 \pm 1.1$ & \multicolumn{2}{c}{$1.3 \pm 0.1$} \\
\hline $\mathrm{B}_{12}-\mathrm{Mn}$ & $2.6 \pm 1.4$ & &
\end{tabular}

a Pseudo half-life, determined from UV/Vis spectral studies. b Determined via myoglobin assay.

c (2,2'-bipyridine)-3,4'-dicarboxylic acid manganese tricarbonyl complex.

\subsection{Surface Functionalization, Characterization and DEMs Cellular Interaction}

Surface functionalization of DEMs with $\mathrm{B}_{12}-\mathrm{ZnTCPP}$ and $\mathrm{B}_{12}-\mathrm{Mn}$ was achieved via amide-bond formation with one of the free carboxylic functions available on the molecules and the previously aminated surface of the DEMs (Figure 2). In the case of $\mathrm{B}_{12}$-TCPP and $\mathrm{B}_{12}-\mathrm{ZnTCPP}$, the presence of free carboxylic functions on the porphyrin macrocycle in both cis- and trans-positions to the PEG arm offers the possibility of several binding modes to DEMs. Given the fact that $\mathrm{B}_{12}$-ZnTCPP-DEMs interact strongly with cancer cells (Figure 2) we posit either that the trans-4-carboxyphenyl is preferentially favored or that the system is flexible enough so that steric hindrance (i.e., in the case of cis-4-carboxyphenyl binding) does not play a significant role in $\mathrm{B}_{12}$-ZnTCPP-DEMs cell interaction. 
Successful surface functionalization of diatoms microalgae was assessed via solid-state UV-Vis spectroscopy (Figure 2D,E). For $\mathrm{B}_{12}$-TCPP-DEMs, comparison of the spectra of the new material to the non-functionalized DEMs, shows new absorbance peaks at $362 \mathrm{~nm}$ (Soret band of vitamin $B_{12}$ ), $423 \mathrm{~nm}$ (Soret band TCPP), 518, 552, 591, and $648 \mathrm{~nm}$ ( $Q$-bands of TCPP). By further reacting $B_{12}$-TCPP-DEMs with zinc acetate in methanol under reflux, metalation of the porphyrin centers occurred, leading to $\mathrm{B}_{12}$-ZnTCPP-DEMs. The solid-state UV-Vis spectrum of $\mathrm{B}_{12}$-ZnTCPP-DEMs compared to the non-metaled equivalent shows a bathochromic shift of the TCPP Soret band to $432 \mathrm{~nm}$ and coalescence of the $Q$-bands to two peaks at 561 and $601 \mathrm{~nm}$ (Figure 2E). This evidence confirmed the successful metalation of the material. Similarly, solid-state UV-Vis spectroscopy was performed to evaluate the newly synthetized material $B_{12}$-Mn-DEMs. When comparing the DEMs spectra before and after surface functionalization with pure $\mathrm{Mn}, \mathrm{B}_{12}$ and $\mathrm{B}_{12}-\mathrm{Mn}$, the appearance of new peaks corresponding to each compound could be observed (Figure 2D). For the Mn-DEMs (synthetized to assess the feasibility of the surface coating), a peak at 431 corresponding to the mLCT absorbance spectrum of the Mn complex is detected. In the case of $B_{12}$-DEMs [25], peaks at $361 \mathrm{~nm}, 521 \mathrm{~nm}$ and $545 \mathrm{~nm}$ are consistent with absorbance of pure cyanocobalamin [72]. Finally, the spectrum of $\mathrm{B}_{12}$-Mn-DEMs shows peaks corresponding to cobalamin at $363 \mathrm{~nm}, 515 \mathrm{~nm}$ and $545 \mathrm{~nm}$ as well as a very small peak at $423 \mathrm{~nm}$ attributed to the presence of Mn. The solid-state UV-Vis spectrum of $B_{12}-\mathrm{Mn}$-DEMs is consistent with the spectrum of $B_{12}-\mathrm{Mn}$ in solution (Figure S13), which shows a signal at $420 \mathrm{~nm}$, very low in intensity when compared to the peaks attributed to the vitamin $B_{12}$ at 361,521 and $545 \mathrm{~nm}$.

Further direct characterization of successful DEMs surface functionalization came from zeta potential ( $\zeta$-potential) analysis of $B_{12}$-ZnTCPP-DEMs. Zeta potential of different samples of DEMs were recorded in PBS buffer at $\mathrm{pH}$ 7.4. Clean hydroxylated diatoms (DEMs-OH) expressed a negative potential of $-23.4 \pm 0.5 \mathrm{mV}$, which shifted to positive $+9.5 \pm 0.4 \mathrm{mV}$ upon surface amination with APTES. This positive shift is indicative of amine functions on DEMs, which can be easily protonated in the buffer [25,73-75]. Further functionalization with TCPP moves the $\zeta$-potential back towards the negative value of $-53.0 \pm 0.4 \mathrm{mV}$, logically deriving from the presence of carboxylic acid groups. The same potential slightly increases to $-48.8 \pm 0.3 \mathrm{mV}$ for $\mathrm{B}_{12}$-TCPP-DEMs and remained virtually the same following $\mathrm{Zn}$ metalation for $\mathrm{B}_{12}$-ZnTCPP-DEMs $(-47.1 \pm 0.2 \mathrm{mV})$.

The surface functionalization of $\mathrm{B}_{12}$-Mn-DEMs and $\mathrm{B}_{12}$-TCPP-DEMs, as well as the resistance of the surface coating in simulated gastric fluid, were assessed by inductively coupled plasma atomic emission spectroscopy (ICP-OES). Naturally occurring diatoms microalgae may contain small traces of cobalt in their frustules composition but considerable traces of manganese [76]. For example, in Cyclotella meneghiniana and Stephanodiscus hantzschii, common freshwater diatom species, zinc and manganese compete for cell wall incorporation with Mn accumulating preferentially at the girdle band of frustules $[77,78]$. In contrast, cobalt can only replace zinc when this ion is totally absent from the growth medium [79]. ICP-OES measurements of the cobalt content in clean DEMs indicated values below the limit of quantification (4 ppm). The difficulty of generating Co ions from cobalamin in the plasma has been reported before [80]; nevertheless, the method we used in the present study was already proven efficient to determine about $95 \%$ of the $B_{12}$ present in a sample [25]. The $B_{12}$-equivalent content was extrapolated from Co concentration of each sample after $2 \mathrm{~h}$ digestion in SGF. $\mathrm{B}_{12}$-Mn-DEMs showed concentrations of $450 \pm 19 \mathrm{ppm}$ and $131 \pm 10 \mathrm{ppm}$ of $B_{12}$ for supernatant and solid residue, respectively. $B_{12}$-TCPP-DEMs showed concentrations of $224 \pm 28 \mathrm{ppm}$ and $92 \pm 21 \mathrm{ppm}$ of $\mathrm{B}_{12}$ for supernatant and solid residue, respectively. Results mean that ca. $29 \%$ and ca. $41 \%$ of the surface coating remain intact after $2 \mathrm{~h}$ in the stomach for $\mathrm{B}_{12}$-Mn-DEMs and $\mathrm{B}_{12}$-TCPP-DEMs, respectively. We plan to coat with gel to increase performance.

Scanning electron microscopy was used to assess the adherence of $\mathrm{B}_{12}-\mathrm{ZnTCPP}$ and $\mathrm{B}_{12}-\mathrm{Mn}$ on colorectal cancer HCT-116 cells. In order to demonstrate cellular adherence, cells were treated with either unmodified (DEMs) and $\mathrm{B}_{12}$-functionalized diatoms under identical conditions (200 $\mu \mathrm{g}$ biomaterial $\mathrm{mL}^{-1}, 1 \mathrm{~h}$ exposure). After intensive washes, cells exposed to $\mathrm{B}_{12}$-functionalized diatoms 
still presented and retained a large amount of micro-particles (Figure 2I,L), while in the sample of unmodified DEMs, almost all the micro-particles were removed via the washing steps.

\subsection{In vitro Drug Loading and Release from Diatom Microalgae}

We have recently described the anti-proliferative efficacy of a series of rhenium(I) tricarbonyl $\mathrm{N}$-derivatized $\mathrm{N}$-((2,2'-bipyridin)-6-ylmethyl) complexes of increasing lipophilicity against different cell lines [48]. Among the series of these compounds, the $f a c-\left(\operatorname{Re}(\mathrm{CO})_{3} \mathrm{Br}\right)$ complexes with 6-(bromomethyl)-2,2'-bipyridine (1 in this study, Figure 4) and $N$-((2,2'-bipyridin)-6-ylmethyl)- $N$-isobutyl-2-methylpropan-1-amine (2, Figure 4) showed excellent in vivo toxicity profiles and in vivo anticancer/antimetastatic efficacy and effective inhibition of angiogenesis in the zebrafish-human CRC tumor xenograft model [48]. These two complexes were selected for the present study. The molecules were successfully loaded into DEMs according to the vacuum infiltration method described by Vasani et al. [81] (giving $1 @ \mathrm{~B}_{12}$-ZnTCPP-DEMs and $2 @ \mathrm{~B}_{12}-\mathrm{Mn}$-DEMs, respectively) with respective loading degrees of 3.7 (1) and 1.5 (2) wt $\%$ (Table 2). These are in the typical range of drugs loaded into DEMs biosilicas [25,26,82-84]. The drug-material composite selection was based on the most favorable drug-release characteristics for each combination. Following successful encapsulation, the drug release in PBS buffer $\mathrm{pH} 7.4$ (1\% v/v, DMSO) was initiated by the addition of solvent and monitored by UV-VIS spectroscopy over a period of 5 days in both cases. As often observed in different studies, an important initial burst release occurs during the first hours (Figure 4) [27,29]. Ca. 60\% and 50\% of complexes 1 and 2 were respectively released in solution after the first hour. A second more gradual and sustained release was then observed over the course of a few days. Indeed, $\mathbf{1}$ and $\mathbf{2}$ were nearly completely discharged from $\mathrm{B}_{12}$-ZnTCPP-DEMs and $\mathrm{B}_{12}$-Mn-DEMs after 2 and 5 days, respectively.

A
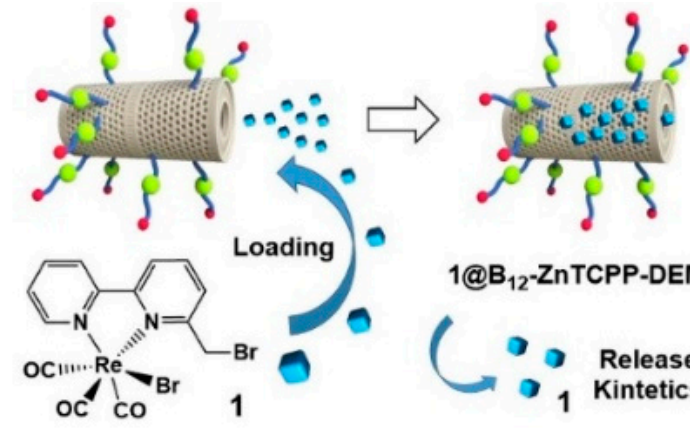

@ $\mathrm{B}_{12}$-ZnTCPP-DEMS

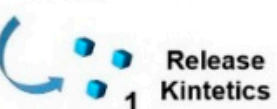

1 Kintetics

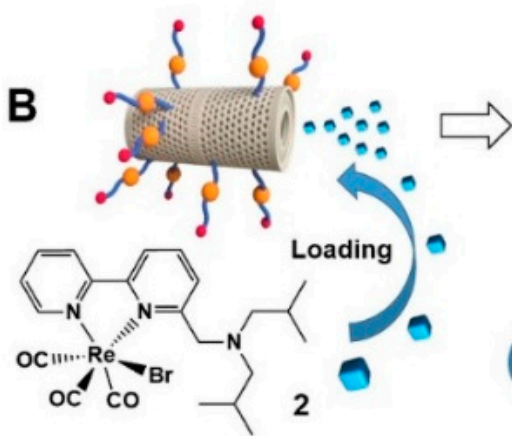

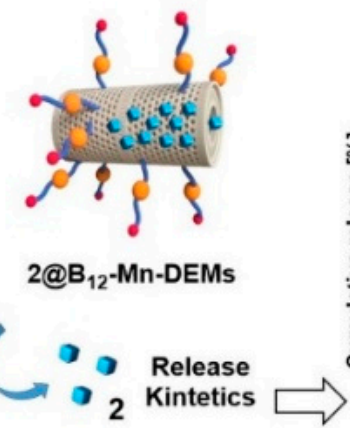
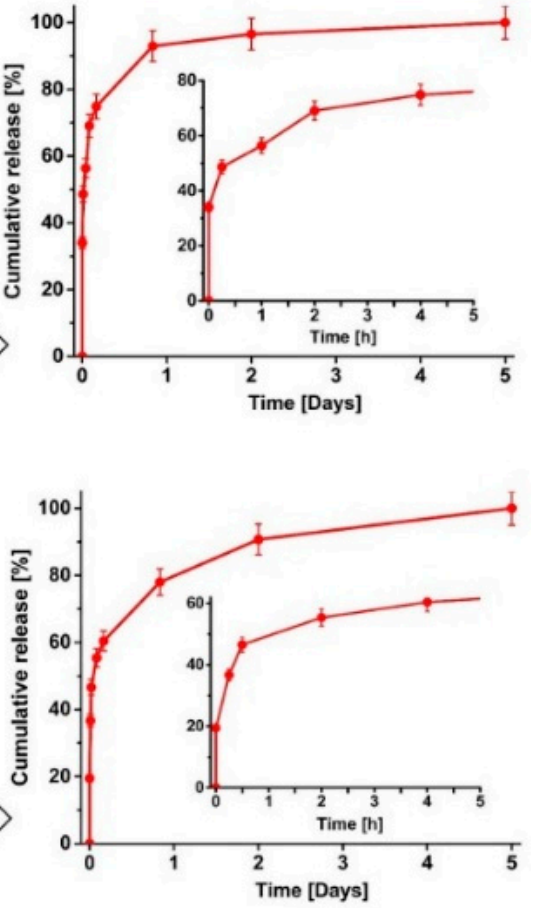

Figure 4. (A) Representative loading of $\mathrm{B}_{12}$-ZnTCPP-DEMs with complex 1 (giving $1 @ \mathrm{~B}_{12}-\mathrm{ZnTCPP}-\mathrm{DEMs}$ ) and graph showing the release of 1 from $B_{12}$-ZnTCPP-DEMs over a period of 5 days (insert shows release in the first $5 \mathrm{~h}$ ). (B) Representative loading of $\mathrm{B}_{12}-\mathrm{Mn}$-DEMs with complex 2 (giving $2 @ \mathrm{~B}_{12}-\mathrm{Mn}$-DEMs)

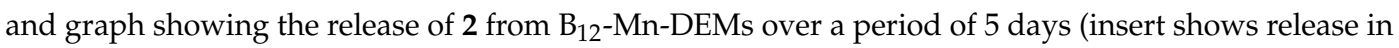
the first $5 \mathrm{~h}$ ). 
Table 2. Loading degrees of rhenium complexes $\mathbf{1}$ and $\mathbf{2}$ in \% wt into DEMs and in vitro cytotoxicity (HCT-116 cells, $\left.\mathrm{IC}_{50}, \mu \mathrm{M}\right)$ of complexes and when administered free, in DEMs in the dark (@ $\mathrm{B}_{12}-\mathrm{X}$-DEMs) and in DEMs following photoactivation of their surface $\left(\mathrm{B}_{12}-X-\mathrm{DEMs}-\lambda \nu\right)$.

\begin{tabular}{ccc}
\hline Compound & $\mu \mathrm{g}$ drug/mg DEMs & IC $_{\mathbf{5 0}}, \boldsymbol{\mu M}$ \\
\hline $\mathbf{1}$ & & $5.0 \pm 0.1$ \\
\hline $\mathbf{1} @ \mathrm{~B}_{12}-\mathrm{ZnTCPP}-\mathrm{DEMs}$ & $38.9(3.7 \%)$ & $4.7 \pm 0.1$ \\
\hline $\mathbf{1} @ \mathrm{~B}_{12}-\mathrm{ZnTCPP}-\mathrm{DEMs}-\lambda \nu$ & $38.9(3.7 \%)$ & $1.2 \pm 0.1$ \\
\hline $\mathbf{2}$ & & $6.2 \pm 0.2$ \\
\hline $\mathbf{2} @ \mathrm{~B}_{12}-\mathrm{Mn}-\mathrm{DEMs}$ & $15.9(1.6 \%)$ & $6.0 \pm 0.2$ \\
\hline $\mathbf{2} @ \mathrm{~B}_{12}-\mathrm{Mn}-\mathrm{DEMs}-\lambda \nu$ & $15.9(1.6 \%)$ & $3.1 \pm 0.1$ \\
\hline
\end{tabular}

\subsection{PDT and Cytotoxicity Assessment}

The cytotoxicity of the $1 \mathrm{~B}_{12}$-ZnTCPP-DEMs and $2 @ \mathrm{~B}_{12}$-Mn-DEMs formulations in dark and under light irradiation were assessed using the human colorectal HCT-116 cell line (Figures 5 and 6). In the case of $1 @ \mathrm{~B}_{12}$-ZnTCPP-DEMs, light activation promotes singlet oxygen generation by the ZnTCPP component. Photoactivation of $1 @ \mathrm{~B}_{12}$-ZnTCPP-DEMs increased the cytotoxicity of the construct up to 2.4-fold for the most concentrated sample ( $\lambda v 200 \mu \mathrm{g} / \mathrm{mL}\left(+\mathrm{IC}_{50}\right)$, Figure 5 and Table 2$)$ when compared to the effects of the administration of $\mathbf{1}$ alone. Notably, $1 \mathrm{~B}_{12}$-ZnTCPP-DEMs containing only $25 \%$ of the $\mathrm{IC}_{50}$ concentration value of $\mathbf{1}$, caused a $45 \%$ increase in cell death upon light exposure in comparison to dark conditions, essentially reaching the cell-killing effects of the $\mathrm{IC}_{50}$ value of $\mathbf{1}$ at $\frac{1}{4}$ the complex concentration. 1@ $\mathrm{B}_{12}-\mathrm{ZnTCPP}$-DEMs with $2.5 \%$ the $\mathrm{IC}_{50}$ of $\mathbf{1}$ caused an increase of $14 \%$ of cell death under tested similar conditions. Overall, as it can be appreciated from the graphs in Figure 5 that the data suggest that lower amounts of cytotoxic compounds are needed in combination with the photoactivatable surface-functionalized diatom microalgae for an equally effective drug formulation or cytotoxic effect. Unmodified natural DEMs, either in the dark or exposed to light, showed no toxicity at concentrations $>100 \mu \mathrm{g} / \mathrm{mL}$, while both DEMs containing adsorbed 1 and $\mathrm{B}_{12}$-TCPP-DEMs particles alone showed slightly higher activity upon the light exposure (Figure 5). The photoactivity of complex 1 was somewhat surprising. We posit that it may be due to activation of the pending $\alpha$-diimine ligand- $\mathrm{CH}_{2}-\mathrm{Br}$ arm towards nucleophilic substitution with bio-available amines via reactions of the complexes previously [48].

For $2 @ \mathrm{~B}_{12}-\mathrm{Mn}$-DEMs, light activation induces $\mathrm{CO}$ release from the photoCORM Mn component at the surface of the microalgae. CO released from this type of molecule is known to promote pro-apoptotic effects in different cancer cell lines [85-90] via CO-mediated attenuation of glutathione and nuclear metallothionein levels [91] and inhibition of cystathionine $\beta$-synthase [92]. When HCT-116 cells were exposed to $2 @ \mathrm{~B}_{12}-\mathrm{Mn}$-DEMs, photoactivation of the material similarly increased the overall cytotoxicity effect of complex 2 . Light irradiation of $2 @ \mathrm{~B}_{12}-\mathrm{Mn}$-DEMs increased the cytotoxicity of the construct by ca. 2.0-fold in the case of the most concentrated sample ( $\lambda v 200 \mu \mathrm{g} / \mathrm{mL}\left(+\mathrm{IC}_{50}\right)$, Figure 6 and Table 2) when compared to the same sample in the dark or to the effects of the administration of 2 alone. In particular, $2 @ \mathrm{~B}_{12}$-Mn-DEMs containing $25 \%$ of the $\mathrm{IC}_{50}$ concentration value of 2 caused a $31 \%$ increase in cell death upon light exposure in comparison to dark conditions. Photoactivation of $2 @ \mathrm{~B}_{12}$-Mn-DEMs containing $\frac{1}{2}$ the $\mathrm{IC}_{50}$ concentration value of 2 was more effective than administration of 2 alone at its $\mathrm{IC}_{50}$ concentration or $\mathrm{B}_{12}$-Mn-DEMs, inducing ca. $64 \%$ cell death. Photoactivation of $2 @ \mathrm{~B}_{12}-\mathrm{Mn}$-DEMs containing only $2.5 \%$ of the same $\mathrm{IC}_{50}$ was not effective but still induced a $13 \%$ increase of cell death compared to the same concentrations of 2 or $\mathrm{B}_{12}$-Mn-DEMs. As concluded for $1 \mathrm{~B}_{12}-\mathrm{ZnTCPP}-\mathrm{DEMs}$, the data for $2 \mathrm{~B}_{12}-\mathrm{Mn}$-DEMs also suggest a potential of this poly-systemic approach in cancer treatment. 


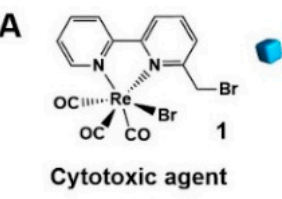

Photochemical reaction at microalgae surface sites

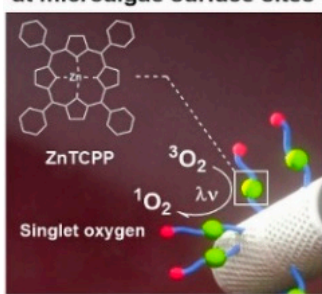

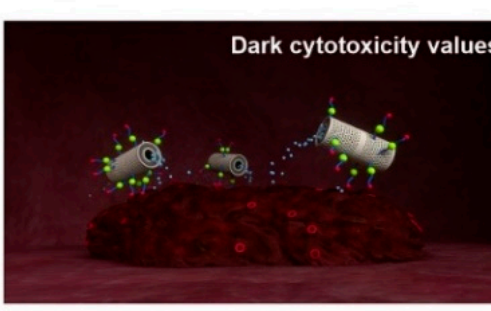

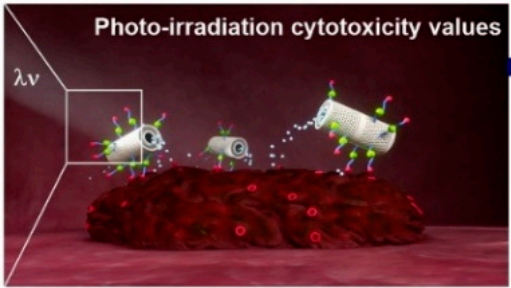

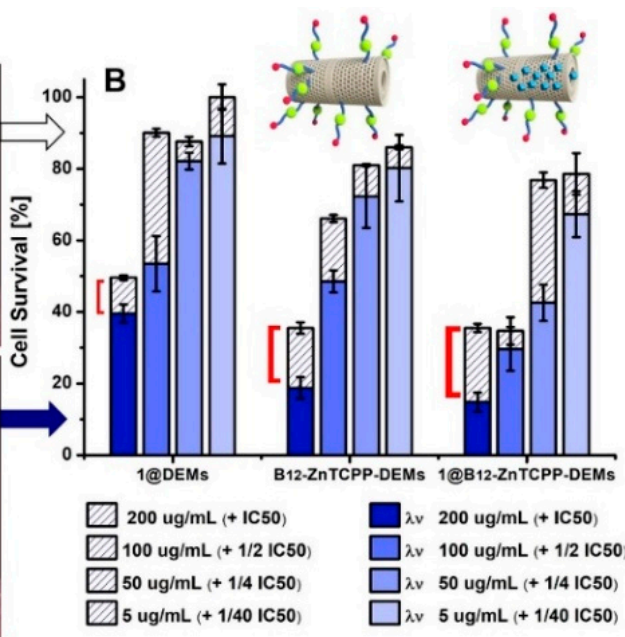

Figure 5. (A) Conceptual representation of the experiment, structure of complex $\mathbf{1}$ and detail of the photochemical reaction taking place at the microalgae surface sites (ZnTCPP-induced ${ }^{1} \mathrm{O}_{2}$ generation). (B) Histograms representing the effects on HCT-116 colorectal cancer cells \% survival by different doses of $1 @$ DEMs, $B_{12}$-ZnTCPP-DEMs and $1 @ B_{12}$-ZnTCPP-DEMs when administered in the dark (empty bars) and under the same conditions following light activation of the microalgae surface (filled colored bars). The red square brackets on the graph are meant to highlight the enhanced cytotoxicity of the material upon photo-irradiation.
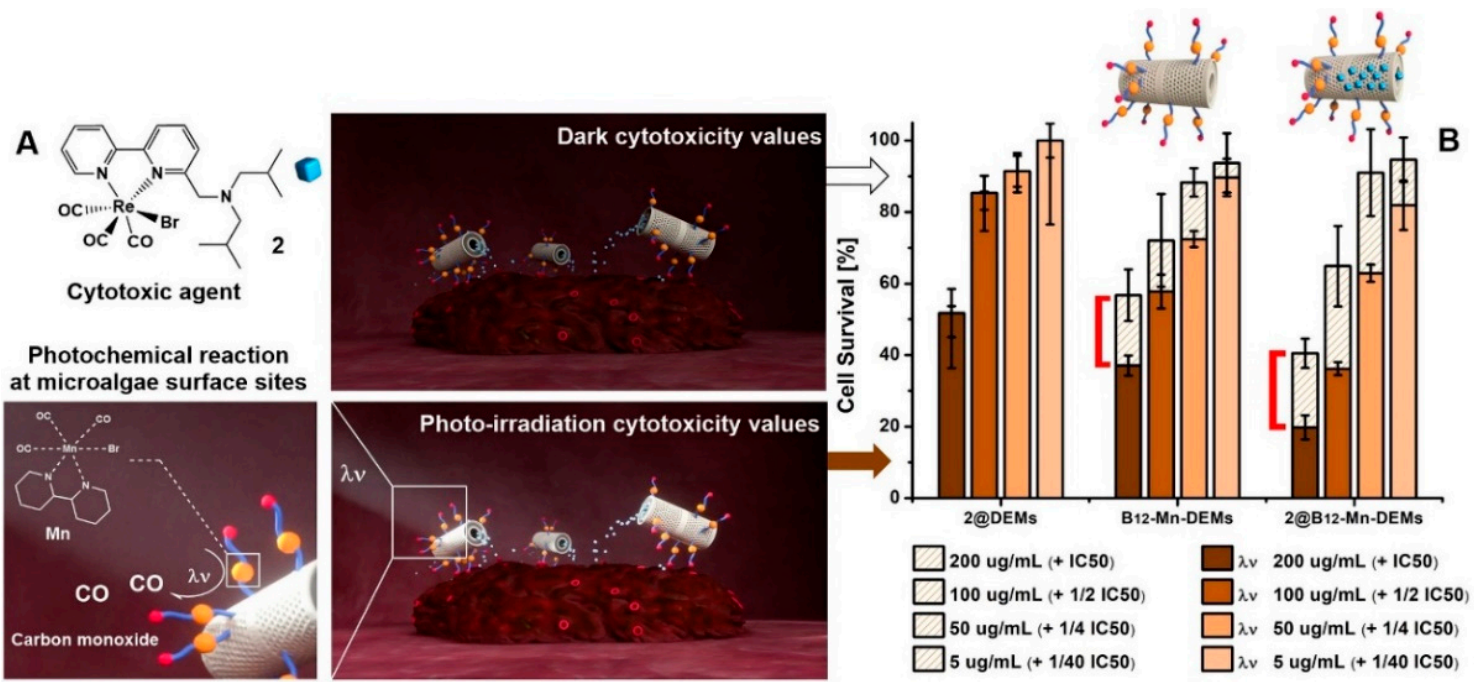

Figure 6. (A) Conceptual representation of the experiment, structure of complex 2 and detail of the photochemical reaction taking place at the microalgae surface sites (CO release from Mn complex). (B) Histograms representing the effects on HCT-116 colorectal cancer cells \% survival by different doses of $2 @ D E M s, B_{12}$-Mn-DEMs and 2@ $\mathrm{B}_{12}$-Mn-DEMs when administered in the dark (empty bars) and under the same conditions following light activation of the microalgae surface (filled colored bars). The red square brackets on the graph are meant to highlight the enhanced cytotoxicity of the material upon photo-irradiation.

Finally, by plotting the delta percentage of cell death measured upon light irradiation of raw DEMs, $\mathrm{B}_{12}$-ZnTCPP-DEMs, $\mathrm{B}_{12}-\mathrm{Mn}$-DEMs and their respective combinations with rhenium anticancer complexes 1 and $\mathbf{2}$ (Figure 7) clearly demonstrate the improved efficiency of this approach (data not shown for raw DEMs alone, which are non-toxic). Data confirm the additive (and possible synergistic) effect of drugs 1 and 2 together with the ${ }^{1} \mathrm{O}_{2}$-generating porphyrin and the CO-releasing photoCORM-functionalized microalgae surface, respectively. 

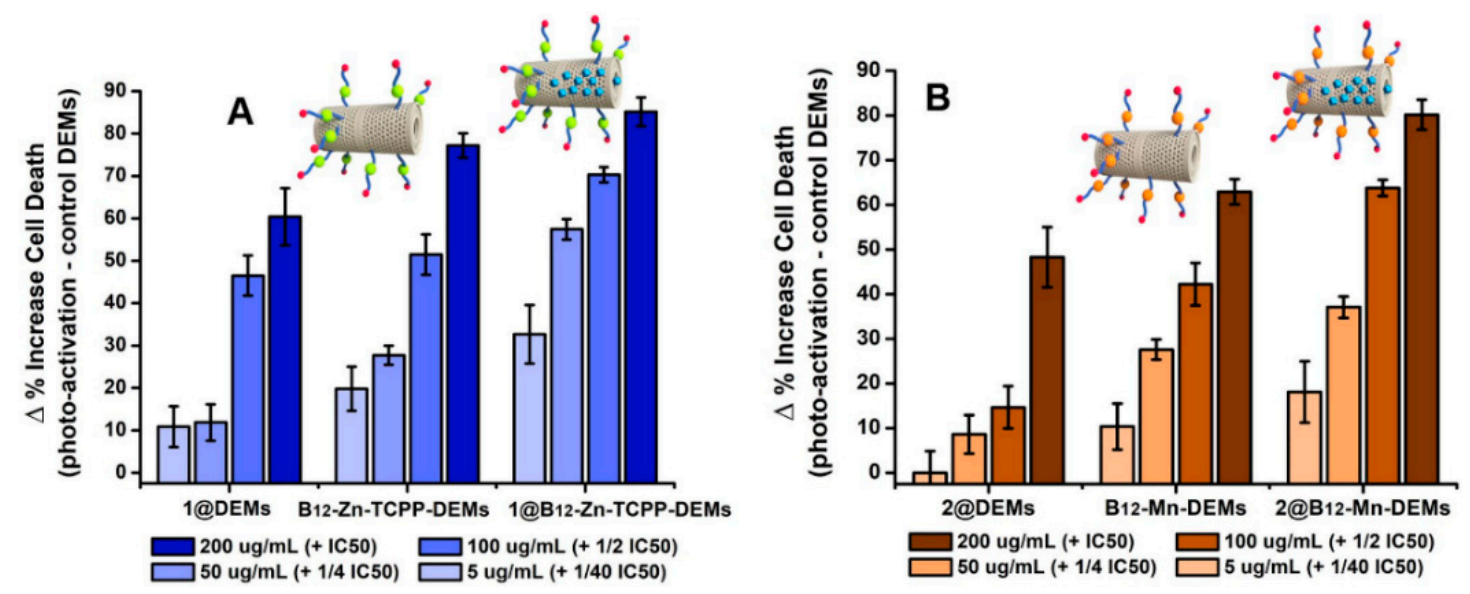

Figure 7. (A,B) Histograms representing the effect of light activation on different doses of $1 @ \mathrm{~B}_{12}$-ZnTCPP-DEMs and $2 @ \mathrm{~B}_{12}$-Mn-DEMs, respectively, on HCT-116 colorectal cancer cells.

\section{Conclusions}

In this study, we have reported the synthesis and characterization of two bio-inspired hybrid multifunctional drug delivery systems based on diatom microalgae. Both photoactivatable materials, either bearing a tetracarboxyphenyl porphyrin PS or tricarbonyl bipyridyl Mn(I) photo-CORM, are able to bind to HCT-116 colorectal cancer cells via the outer cobalamin layer and slowly release highly active rhenium(I) tricarbonyl anticancer complexes. The ability of the $\mathrm{B}_{12}$-X-DEMs micro-particles to retain a high level of surface functionalization in simulated gastric fluids was also demonstrated. Furthermore, the potentiation effect of the chemotoxic drug by the different light-activated molecules at the surface of diatom microalgae was demonstrated by MTT assay under dark/light conditions on the HCT-116 cell line. At least a 2-fold increase of cytotoxicity toward HCT-116 was observed upon light irradiaton for both constructs (at $200 \mu \mathrm{g} \mathrm{mL}^{-1}$, incubated with drug concentration corresponding to respective $\mathrm{IC}_{50}$ values) with cell survival falling from ca. $40 \%$ to ca. $20 \%$. Our results are in line with what was reported earlier in the literature for different constructs [93-97], indicating that synergistic chemo-photodynamic therapy mediated by diatom microalgae is a strategy worth pursuing in colon-focused drug delivery. It is well known that undesirable side effects of most chemotherapeutics like cisplatin are dose-dependent [98]; thus, this approach can reduce the need for chemotherapeutics concentration for equal effectiveness, hence leading to diminished undesirable side effects for the patient. Future efforts for the optimization of this hybrid multifunctional drug delivery system will be directed towards coating formulations (e.g., $\mathrm{pH}$-dependent polymers such as cellulose acetate phthalates, hydroxypropyl methyl-cellulose phthalate or biodegradable liposomes) that can respond to dynamic $\mathrm{pH}$ changes of the gastro-intestinal (GI) tract in order to expose the active material in the colon only. This approach should further increase surface coating retention after the passage through the stomach in future formulations.

Supplementary Materials: The following are available online at http://www.mdpi.com/1999-4923/12/5/480/s1: Figure S1: ${ }^{1} \mathrm{H}-\mathrm{NMR}$ of TCPP; Figure S2: ${ }^{1} \mathrm{H}-\mathrm{NMR}$ of $\mathrm{B}_{12}$-TCPP; Figure S3: ${ }^{1} \mathrm{H}-\mathrm{NMR}$ of TCPP-1; Figure S4: ${ }^{1} \mathrm{H}-\mathrm{NMR}$ of $\mathrm{B}_{12}-\mathrm{Mn}$; Figure S5: MS spectrum of $\mathrm{B}_{12}$-TCPP; Figure S6: MS spectrum of TCPP-1; Figure S7: Fluorescence spectra of PEG-ZnTCPP and $\mathrm{B}_{12}-\mathrm{ZnTCPP}$; Figure S8: Fluorescence lifetime decay curves of $\mathrm{B}_{12}-\mathrm{ZnTCPP}$ and ZnTCPP-1; Figure S9: IR of Mn; Figure S10: IR of $\mathrm{B}_{12}-\mathrm{Mn}$; Figure S11: HPLC chromatogram of $\mathrm{B}_{12}-\mathrm{TCPP}$; Figure S12: UV/Vis of Mn; Figure S13: UV/Vis of $\mathrm{B}_{12}-\mathrm{Mn}$; Figure S14: Solid state UV/Vis of DEMs, Mn-DEMs, $\mathrm{B}_{12}$-DEMs and $\mathrm{B}_{12}$-Mn-DEMs; Figure S15: Solid state UV/Vis of DEMs, $\mathrm{B}_{12}$-TCPP-DEMs and $\mathrm{B}_{12}$-ZnTCPP-DEMs; Figure S16: Concentration of Mb-CO upon light irradiation of Mn; Figure S17: Concentration of Mb-CO upon light irradiation of $\mathrm{B}_{12}-\mathrm{Mn}$; Figure S18: Spectral changes at $410 \mathrm{~nm}$ of Mn upon light irradiation; Figure S19: Spectral changes at $410 \mathrm{~nm}$ of $\mathrm{B}_{12}-\mathrm{Mn}$ upon light irradiation; Figure S20: Mn absorption decrease at $410 \mathrm{~nm}$ regarding irradiation time; Figure S21: $\mathrm{B}_{12}-\mathrm{Mn}$ absorption decrease at $365 \mathrm{~nm}$ regarding irradiation time; Figure S22: Calculated IR spectrum of $\mathrm{B}_{12}-\mathrm{Mn}$ (gas phase b3lyp/lanl2dz); Table S1: List of calculated IR frequencies for $\mathrm{B}_{12}-\mathrm{Mn}^{-}$ (gas phase b3lyp/lanl2dz); Figure S23: Calculated IR spectrum of $\mathrm{B}_{12}$-TCPP (gas phase b3lyp/lanl2dz); Table S2: List of calculated IR frequencies for $\mathrm{B}_{12}$-TCPP (gas phase b3lyp/lanl2dz). 
Author Contributions: Conceptualization, J.D. and F.Z.; methodology, J.D., P.S., S.V. and J.N.-R.; software, J.N.-R. and J.D.; validation, J.D., P.S., S.V., J.N.-R. and F.Z.; formal analysis, J.D., P.S., S.V. and J.N.-R.; investigation, J.D., P.S., S.V., J.N.-R. and F.Z.; resources, F.Z.; data curation, J.D.; writing-original draft preparation, J.D., P.S., S.V., J.N.-R. and F.Z.; writing-review and editing, J.D., S.V., J.N.-R. and F.Z.; visualization, J.D. and F.Z.; supervision, F.Z.; project administration, F.Z.; funding acquisition, F.Z. All authors have read and agreed to the published version of the manuscript.

Funding: Financial support from the Swiss National Science Foundation (Grant\# PP00P2_170589 to J.D. and F.Z.), the University of Fribourg and the Institute of molecular Genetics and Genetic Engineering from the University of Belgrade (Ministry of Education, Science and Technological Development of the Republic of Serbia, Project No.173048 (to S.V. and J.N.-R.) are gratefully acknowledged.

Conflicts of Interest: The authors declare no conflict of interest.

\section{References}

1. Kim, W.; Lee, Y.; Jeong, S.; Nam, J.; Lee, S.; Jung, Y. Colonic delivery of celecoxib is a potential pharmaceutical strategy for repositioning the selective COX-2 inhibitor as an anti-colitic agent. Arch. Pharm. Res. 2015, 38, 1830-1838. [CrossRef] [PubMed]

2. Jain, S.K.; Tiwari, A.; Jain, A.; Verma, A.; Saraf, S.; Panda, P.K.; Gour, G. Application Potential of Polymeric Nanoconstructs for Colon-Specific Drug Delivery. In Multifunctional Nanocarriers for Contemporary Healthcare Applications; IGI Global: Hershey, PA, USA, 2018; pp. 22-49. [CrossRef]

3. Zhang, S.; Ermann, J.; Succi, M.D.; Zhou, A.; Hamilton, M.J.; Cao, B.; Korzenik, J.R.; Glickman, J.N.; Vemula, P.K.; Glimcher, L.H.; et al. An inflammation-targeting hydrogel for local drug delivery in inflammatory bowel disease. Sci. Transl. Med. 2015, 7, 300ra128. [CrossRef] [PubMed]

4. Naeem, M.; Awan, U.A.; Subhan, F.; Cao, J.; Hlaing, S.P.; Lee, J.; Im, E.; Jung, Y.; Yoo, J.W. Advances in colon-targeted nano-drug delivery systems: Challenges and solutions. Arch. Pharm. Res. 2020, 43, 153-169. [CrossRef]

5. Lee, S.H.; Bajracharya, R.; min, J.Y.; Han, J.W.; Park, B.J.; Han, H.K. Strategic Approaches for Colon Targeted Drug Delivery: An Overview of Recent Advancements. Pharmaceutics 2020, 12, 68. [CrossRef]

6. Bertoni, S.; Machness, A.; Tiboni, M.; Bartolo, R.; Santos, H.A. Reactive oxygen species responsive nanoplatforms as smart drug delivery systems for gastrointestinal tract targeting. Biopolymers 2020, 111, e23336. [CrossRef]

7. Servatan, M.; Zarrintaj, P.; Mahmodi, G.; Kim, S.J.; Ganjali, M.R.; Saeb, M.R.; Mozafari, M. Zeolites in drug delivery: Progress, challenges and opportunities. Drug Discov. Today 2020. [CrossRef]

8. Huang, X.; Wu, W.; Yang, W.; Qing, X.; Shao, Z. Surface engineering of nanoparticles with ligands for targeted delivery to osteosarcoma. Colloids Surf. B 2020, 190, 110891. [CrossRef]

9. Hu, X.L.; Kwon, N.; Yan, K.C.; Sedgwick, A.C.; Chen, G.R.; He, X.P.; James, T.D.; Yoon, J. Bio-Conjugated Advanced Materials for Targeted Disease Theranostics. Adv. Funct. Mater. 2020. [CrossRef]

10. Yu, W.; Liu, R.; Zhou, Y.; Gao, H. Size-Tunable Strategies for a Tumor Targeted Drug Delivery System. ACS Cent. Sci. 2020, 6, 100-116. [CrossRef]

11. Pinelli, F.; Perale, G.; Rossi, F. Coating and Functionalization Strategies for Nanogels and Nanoparticles for Selective Drug Delivery. Gels 2020, 6, 6. [CrossRef]

12. Narayanaswamy, R.; Torchilin, V.P. Hydrogels and Their Applications in Targeted Drug Delivery. Molecules 2019, 24, 603. [CrossRef] [PubMed]

13. Moosavian, S.A.; Sahebkar, A. Aptamer-functionalized liposomes for targeted cancer therapy. Cancer Lett. 2019, 448, 144-154. [CrossRef] [PubMed]

14. Kavand, A.; Anton, N.; Vandamme, T.; Serra, C.A.; Chan-Seng, D. Synthesis and functionalization of hyperbranched polymers for targeted drug delivery. J. Control. Release 2020, 321, 285-311. [CrossRef] [PubMed]

15. Prajapati, S.K.; Jain, A.; Jain, A.; Jain, S. Biodegradable polymers and constructs: A novel approach in drug delivery. Eur. Polym. J. 2019, 120. [CrossRef]

16. Cai, M.; Chen, G.; Qin, L.; Qu, C.; Dong, X.; Ni, J.; Yin, X. Metal Organic Frameworks as Drug Targeting Delivery Vehicles in the Treatment of Cancer. Pharmaceutics 2020, 12, 232. [CrossRef] [PubMed]

17. He, Z.; Zhang, Y.; Feng, N. Cell membrane-coated nanosized active targeted drug delivery systems homing to tumor cells: A review. Mater. Sci. Eng. C-Mater. 2020, 106, 110298. [CrossRef] 
18. Girisa, S.; Shabnam, B.; Monisha, J.; Fan, L.; Halim, C.E.; Arfuso, F.; Ahn, K.S.; Sethi, G.; Kunnumakkara, A.B. Potential of Zerumbone as an Anti-Cancer Agent. Molecules 2019, 24, 734. [CrossRef]

19. Salleh, N.; Jais, U.S.; Sarijo, S.H. Gelatin-coated zeolite y for controlled release of anticancer drug (zerumbone). In Proceedings of the 2012 IEEE Symposium on Business, Engineering and Industrial Applications, Bandung, Indonesia, 23-26 September 2012; pp. 124-129.

20. Li, W.; Liu, D.; Zhang, H.; Correia, A.; Makila, E.; Salonen, J.; Hirvonen, J.; Santos, H.A. Microfluidic assembly of a nano-in-micro dual drug delivery platform composed of halloysite nanotubes and a $\mathrm{pH}$-responsive polymer for colon cancer therapy. Acta Biomater. 2017, 48, 238-246. [CrossRef]

21. Xu, J.; Xu, L.; Wang, C.; Yang, R.; Zhuang, Q.; Han, X.; Dong, Z.; Zhu, W.; Peng, R.; Liu, Z. Near-Infrared-Triggered Photodynamic Therapy with Multitasking Upconversion Nanoparticles in Combination with Checkpoint Blockade for Immunotherapy of Colorectal Cancer. ACS Nano 2017, 11, 4463-4474. [CrossRef]

22. Mohd-Zahid, M.H.; Mohamud, R.; Abdullah, C.A.C.; Lim, J.; Alem, H.; Hanaffi, W.N.W.; Iskandar, Z.A. Colorectal cancer stem cells: A review of targeted drug delivery by gold nanoparticles. RSC Adv. 2020, 10, 973-985. [CrossRef]

23. Zwicke, G.L.; Mansoori, G.A.; Jeffery, C.J. Utilizing the folate receptor for active targeting of cancer nanotherapeutics. Nano Rev. 2012, 3. [CrossRef]

24. Delasoie, J.; Zobi, F. Natural Diatom Biosilica as Microshuttles in Drug Delivery Systems. Pharmaceutics 2019, 11, 537. [CrossRef] [PubMed]

25. Delasoie, J.; Rossier, J.; Haeni, L.; Rothen-Rutishauser, B.; Zobi, F. Slow-targeted release of a ruthenium anticancer agent from vitamin $\mathrm{B}_{12}$ functionalized marine diatom microalgae. Dalton Trans. 2018, 47, 17221-17232. [CrossRef] [PubMed]

26. Aw, M.S.; Bariana, M.; Yu, Y.; Addai-Mensah, J.; Losic, D. Surface-functionalized diatom microcapsules for drug delivery of water-insoluble drugs. J. Biomater. Appl. 2013, 28, 163-174. [CrossRef] [PubMed]

27. Ruggiero, I.; Terracciano, M.; Martucci, N.M.; De Stefano, L.; Migliaccio, N.; Tate, R.; Rendina, I.; Arcari, P.; Lamberti, A.; Rea, I. Diatomite silica nanoparticles for drug delivery. Nanoscale Res. Lett. 2014, 9, 329. [CrossRef]

28. Dordelmann, G.; Pfeiffer, H.; Birkner, A.; Schatzschneider, U. Silicium dioxide nanoparticles as carriers for photoactivatable CO-releasing molecules (PhotoCORMs). Inorg. Chem. 2011, 50, 4362-4367. [CrossRef]

29. Bariana, M.; Aw, M.S.; Kurkuri, M.; Losic, D. Tuning drug loading and release properties of diatom silica microparticles by surface modifications. Int. J. Pharm. 2013, 443, 230-241. [CrossRef]

30. Terracciano, M.; De Stefano, L.; Rea, I. Diatoms Green Nanotechnology for Biosilica-Based Drug Delivery Systems. Pharmaceutics 2018, 10, 242. [CrossRef]

31. Maher, S.; Kumeria, T.; Aw, M.S.; Losic, D. Diatom Silica for Biomedical Applications: Recent Progress and Advances. Adv. Healthc. Mater. 2018, 7, e1800552. [CrossRef]

32. Uthappa, U.T.; Brahmkhatri, V.; Sriram, G.; Jung, H.Y.; Yu, J.; Kurkuri, N.; Aminabhavi, T.M.; Altalhi, T.; Neelgund, G.M.; Kurkuri, M.D. Nature engineered diatom biosilica as drug delivery systems. J. Control. Release 2018, 281, 70-83. [CrossRef]

33. Albert, K.; Huang, X.C.; Hsu, H.Y. Bio-templated silica composites for next-generation biomedical applications. Adv. Colloid Interface Sci. 2017, 249, 272-289. [CrossRef] [PubMed]

34. Dougherty, T.J.; Gomer, C.J.; Henderson, B.W.; Jori, G.; Kessel, D.; Korbelik, M.; Moan, J.; Peng, Q. Photodynamic therapy. J. Natl. Cancer Inst. 1998, 90, 889-905. [CrossRef] [PubMed]

35. Callaghan, S.; Senge, M.O. The good, the bad, and the ugly-Controlling singlet oxygen through design of photosensitizers and delivery systems for photodynamic therapy. Photochem. Photobiol. Sci. 2018, 17, 1490-1514. [CrossRef] [PubMed]

36. Spring, B.Q.; Rizvi, I.; Xu, N.; Hasan, T. The role of photodynamic therapy in overcoming cancer drug resistance. Photochem. Photobiol. Sci. 2015, 14, 1476-1491. [CrossRef]

37. Lovell, J.F.; Liu, T.W.; Chen, J.; Zheng, G. Activatable photosensitizers for imaging and therapy. Chem. Rev. 2010, 110, 2839-2857. [CrossRef]

38. DeRosa, M.C.; Crutchley, R.J. Photosensitized singlet oxygen and its applications. Coord. Chem. Rev. 2002, 233, 351-371. [CrossRef]

39. Abrahamse, H.; Hamblin, M.R. New photosensitizers for photodynamic therapy. Biochem. J. 2016, 473, 347-364. [CrossRef] 
40. Bonnett, R. Photosensitizers of the Porphyrin and Phthalocyanine Series for Photodynamic Therapy. Chem. Soc. Rev. 1995, 24, 19-33. [CrossRef]

41. Sternberg, E.D.; Dolphin, D.; Bruckner, C. Porphyrin-based photosensitizers for use in photodynamic therapy. Tetrahedron 1998, 54, 4151-4202. [CrossRef]

42. Hu, X.; Ogawa, K.; Kiwada, T.; Odani, A. Water-soluble metalloporphyrinates with excellent photo-induced anticancer activity resulting from high tumor accumulation. J. Inorg. Biochem. 2017, 170, 1-7. [CrossRef]

43. Zobi, F. CO and CO-releasing molecules in medicinal chemistry. Future Med. Chem. 2013, 5, 175-188. [CrossRef] [PubMed]

44. Wegiel, B.; Gallo, D.; Csizmadia, E.; Harris, C.; Belcher, J.; Vercellotti, G.M.; Penacho, N.; Seth, P.; Sukhatme, V.; Ahmed, A.; et al. Carbon monoxide expedites metabolic exhaustion to inhibit tumor growth. Cancer Res. 2013, 73, 7009-7021. [CrossRef] [PubMed]

45. Vitek, L.; Gbelcova, H.; Muchova, L.; Vanova, K.; Zelenka, J.; Konickova, R.; Suk, J.; Zadinova, M.; Knejzlik, Z.; Ahmad, S.; et al. Antiproliferative effects of carbon monoxide on pancreatic cancer. Dig. Liver Dis. 2014, 46, 369-375. [CrossRef] [PubMed]

46. Meister, K.; Niesel, J.; Schatzschneider, U.; Metzler-Nolte, N.; Schmidt, D.A.; Havenith, M. Label-free imaging of metal-carbonyl complexes in live cells by Raman microspectroscopy. Angew. Chem. Int. Ed. 2010, 49, 3310-3312. [CrossRef] [PubMed]

47. Kourti, M.; Jiang, W.G.; Cai, J. Aspects of Carbon Monoxide in Form of CO-Releasing molecules Used in Cancer Treatment: More Light on the Way. Oxid. Med. Cell. Longev. 2017, 2017, 9326454. [CrossRef] [PubMed]

48. Delasoie, J.; Pavic, A.; Voutier, N.; Vojnovic, S.; Crochet, A.; Nikodinovic-Runic, J.; Zobi, F. Highly Potent rhenium(I) Tricarbonyl Complexes with Dual Anticancer and Anti-Angiogenic Activity Against Colorectal Carcinoma. ChemRxiv 2020. [CrossRef]

49. Coughlin, J.E.; Pandey, R.K.; Padmanabhan, S.; O'Loughlin, K.G.; Marquis, J.; Green, C.E.; Mirsalis, J.C.; Iyer, R.P. Metabolism, Pharmacokinetics, Tissue Distribution, and Stability Studies of the Prodrug Analog of an Anti-Hepatitis B Virus Dinucleoside Phosphorothioate. Drug Metab. Dispos. 2012, 40, 970-981. [CrossRef]

50. Minenkov, Y.; Singstad, A.; Occhipinti, G.; Jensen, V.R. The accuracy of DFT-optimized geometries of functional transition metal compounds: A validation study of catalysts for olefin metathesis and other reactions in the homogeneous phase. Dalton Trans. 2012, 41, 5526-5541. [CrossRef]

51. Adler, A.D.; Longo, F.R.; Finarelli, J.D.; Goldmach, J.; Assour, J.; Korsakof, L. A Simplified Synthesis for Meso-Tetraphenylporphin. J. Org. Chem. 1967, 32, 476. [CrossRef]

52. Vicente, M.D.; Smith, K.M. Syntheses and Functionalizations of Porphyrin Macrocycles. Curr. Org. Synth. 2014, 11, 3-28. [CrossRef]

53. Shahroosvand, H.; Zakavi, S.; Sousaraei, A.; Mohajerani, E.; Mahmoudi, M. Unusual near-white electroluminescence of light emitting diodes based on saddle-shaped porphyrins. Dalton Trans. 2015, 44, 8364-8368. [CrossRef] [PubMed]

54. McEwan, J.F.; Veitch, H.S.; Russell-Jones, G.J. Synthesis and biological activity of ribose-5'-carbamate derivatives of vitamin B(12). Bioconjug. Chem. 1999, 10, 1131-1136. [CrossRef] [PubMed]

55. Fedosov, S.N.; Grissom, C.B.; Fedosova, N.U.; Moestrup, S.K.; Nexo, E.; Petersen, T.E. Application of a fluorescent cobalamin analogue for analysis of the binding kinetics. A study employing recombinant human transcobalamin and intrinsic factor. FEBS J. 2006, 273, 4742-4753. [CrossRef] [PubMed]

56. Ruggi, A.; Zobi, F. Quantum-CORMs: Quantum dot sensitized CO releasing molecules. Dalton Trans. 2015, 44, 10928-10931. [CrossRef]

57. Rossier, J.; Hauser, D.; Kottelat, E.; Rothen-Rutishauser, B.; Zobi, F. Organometallic cobalamin anticancer derivatives for targeted prodrug delivery via transcobalamin-mediated uptake. Dalton Trans. 2017, 46, 2159-2164. [CrossRef]

58. Korinek, A.; Dedic, R.; molnar, A.; Svoboda, A.; Hala, J. A comparison of photosensitizing properties of meso-tetraphenylporphin in acetone and in dimethyl sulfoxide. J. mol. Struct. 2005, 744, 727-731. [CrossRef]

59. Atkin, A.J.; Lynam, J.M.; Moulton, B.E.; Sawle, P.; Motterlini, R.; Boyle, N.M.; Pryce, M.T.; Fairlamb, I.J. Modification of the deoxy-myoglobin/carbonmonoxy-myoglobin UV-vis assay for reliable determination of CO-release rates from organometallic carbonyl complexes. Dalton Trans. 2011, 40, 5755-5761. [CrossRef]

60. Hansen, M.B.; Nielsen, S.E.; Berg, K. Re-examination and further development of a precise and rapid dye method for measuring cell growth/cell kill. J. Immunol. Methods 1989, 119, 203-210. [CrossRef] 
61. Pettenuzzo, A.; Pigot, R.; Ronconi, L. Vitamin B-12-Metal Conjugates for Targeted Chemotherapy and Diagnosis: Current Status and Future Prospects. Eur. J. Inorg. Chem. 2017, 1625-1638. [CrossRef]

62. Russell-Jones, G.J.; Arthur, L.; Walker, H. Vitamin $\mathrm{B}_{12}$-mediated transport of nanoparticles across Caco-2 cells. Int. J. Pharm. 1999, 179, 247-255. [CrossRef]

63. Clardy, S.M.; Allis, D.G.; Fairchild, T.J.; Doyle, R.P. Vitamin $B_{12}$ in drug delivery: Breaking through the barriers to a $\mathrm{B}_{12}$ bioconjugate pharmaceutical. Expert Opin. Drug Deliv. 2011, 8, 127-140. [CrossRef] [PubMed]

64. Pierini, G.D.; Pinto, V.H.A.; Maia, C.G.C.; Fragoso, W.D.; Reboucas, J.S.; Centurion, M.E.; Pistonesi, M.F.; Di Nezio, M.S. A porphyrin-based fluorescence method for zinc determination in commercial propolis extracts without sample pretreatment. Luminescence 2017, 32, 1227-1232. [CrossRef] [PubMed]

65. Ghosh, M.; Mora, A.K.; Nath, S.; Chandra, A.K.; Hajra, A.; Sinha, S. Photophysics of Soret-excited free base tetraphenylporphyrin and its zinc analog in solution. Spectrochim. Acta A 2013, 116, 466-472. [CrossRef] [PubMed]

66. Figueiredo, T.L.C.; Johnstone, R.A.W.; Sorensen, A.M.P.S.; Burget, D.; Jacques, P. Determination of fluorescence yields, singlet lifetimes and singlet oxygen yields of water-insoluble porphyrins and metalloporphyrins in organic solvents and in aqueous media. Photochem. Photobiol. 1999, 69, 517-528. [CrossRef]

67. De Souza, T.G.B.; Vivas, M.G.; Mendonca, C.R.; Plunkett, S.; Filatov, M.A.; Senge, M.O.; De Boni, L. Studying the intersystem crossing rate and triplet quantum yield of meso-substituted porphyrins by means of pulse train fluorescence technique. J. Porphyr. Phthalocyanines 2016, 20, 282-291. [CrossRef]

68. Zu, G.P.; Wang, J.J.; Zhang, Y.; Chen, W.B.; Shi, Y.Z.; Guo, S.W.; Wang, X.R. Study on Five Porphyrin-Based Photosensitizers for Singlet Oxygen Generation. Chemistryselect 2019, 4, 863-867. [CrossRef]

69. Ricchelli, F. Photophysical Properties of Porphyrins in Biological-Membranes. J. Photochem. Photobiol. B 1995, 29, 109-118. [CrossRef]

70. Diaz-Uribe, C.E.; Daza, M.C.; Paez-Mozo, E.A.; Martinez, F.; Guedes, C.L.B.; Di Mauro, E. Visible light singlet oxygen production with tetra (4-carboxyphenyl) porphyrin/SiO 2 . J. Photochem. Photobiol. A 2013, 259, 47-52. [CrossRef]

71. Jimenez, J.; Chakraborty, I.; Carrington, S.J.; Mascharak, P.K. Light-triggered CO delivery by a water-soluble and biocompatible manganese photoCORM. Dalton Trans. 2016, 45, 13204-13213. [CrossRef]

72. Carkeet, C.; Dueker, S.R.; Lango, J.; Buchholz, B.A.; Miller, J.W.; Green, R.; Hammock, B.D.; Roth, J.R.; Anderson, P.J. Human vitamin $\mathrm{B}_{12}$ absorption measurement by accelerator mass spectrometry using specifically labeled (14) C-cobalamin. Proc. Natl. Acad. Sci. USA 2006, 103, 5694-5699. [CrossRef]

73. Feng, C.; Li, J.; Wu, G.S.; Mu, Y.Z.; Kong, M.; Jiang, C.Q.; Cheng, X.J.; Liu, Y.; Chen, X.G. Chitosan-Coated Diatom Silica as Hemostatic Agent for Hemorrhage Control. ACS Appl. Mater. Interfaces 2016, 8, 34234-34243. [CrossRef] [PubMed]

74. Chen, J.; Qin, G.W.; Chen, Q.; Yu, J.Y.; Li, S.; Cao, F.; Yang, B.; Ren, Y.P. A synergistic combination of diatomaceous earth with Au nanoparticles as a periodically ordered, button-like substrate for SERS analysis of the chemical composition of eccrine sweat in latent fingerprints. J. Mater. Chem. C 2015, 3, 4933-4944. [CrossRef]

75. Yu, Y.; Addai-Mensah, J.; Losic, D. Functionalized diatom silica microparticles for removal of mercury ions. Sci. Technol. Adv. Mater. 2012, 13. [CrossRef] [PubMed]

76. Van Eynde, E.; Hu, Z.Y.; Tytgat, T.; Verbruggen, S.W.; Watte, J.; Van Tendeloo, G.; Van Driessche, I.; Blust, R.; Lenaerts, S. Diatom silica-titania photocatalysts for air purification by bio-accumulation of different titanium sources. Environ. Sci. Nano 2016, 3, 1052-1061. [CrossRef]

77. de Jonge, M.D.; Holzner, C.; Baines, S.B.; Twining, B.S.; Ignatyev, K.; Diaz, J.; Howard, D.L.; Legnini, D.; Miceli, A.; McNulty, I.; et al. Quantitative 3D elemental microtomography of Cyclotella meneghiniana at 400-nm resolution. Proc. Natl. Acad. Sci. USA 2010, 107, 15676. [CrossRef]

78. Jaccard, T.; Ariztegui, D.; Wilkinson, K.J. Incorporation of zinc into the frustule of the freshwater diatom Stephanodiscus hantzschii. Chem. Geol. 2009, 265, 381-386. [CrossRef]

79. Price, N.M.; Morel, F.M.M. Cadmium and cobalt substitution for zinc in a marine diatom. Nature 1990, 344, 658-660. [CrossRef]

80. Bartosiak, M.; Jankowski, K.; Giersz, J. Determination of cobalt species in nutritional supplements using ICP-OES after microwave-assisted extraction and solid-phase extraction. J. Pharm. Biomed. Anal. 2018, 155, 135-140. [CrossRef] 
81. Vasani, R.B.; Losic, D.; Cavallaro, A.; Voelcker, N.H. Fabrication of stimulus-responsive diatom biosilica microcapsules for antibiotic drug delivery. J. Mater. Chem. B 2015, 3, 4325-4329. [CrossRef]

82. Cicco, S.R.; Vona, D.; De Giglio, E.; Cometa, S.; Mattioli-Belmonte, M.; Palumbo, F.; Ragni, R.; Farinola, G.M. Chemically Modified Diatoms Biosilica for Bone Cell Growth with Combined Drug-Delivery and Antioxidant Properties. Chempluschem 2015, 80, 1104-1112. [CrossRef]

83. Terracciano, M.; Shahbazi, M.A.; Correia, A.; Rea, I.; Lamberti, A.; De Stefano, L.; Santos, H.A. Surface bioengineering of diatomite based nanovectors for efficient intracellular uptake and drug delivery. Nanoscale 2015, 7, 20063-20074. [CrossRef] [PubMed]

84. Janicijevic, J.; Milic, J.; Calija, B.; Micov, A.; Stepanovic-Petrovic, R.; Tomic, M.; Dakovic, A.; Dobricic, V.; Vasiljevic, B.N.; Krajisnik, D. Potentiation of the ibuprofen antihyperalgesic effect using inorganically functionalized diatomite. J. Mater. Chem. B 2018, 6, 5812-5822. [CrossRef] [PubMed]

85. Jimenez, J.; Pinto, M.N.; Martinez-Gonzalez, J.; Mascharak, P.K. Photo-induced eradication of human colorectal adenocarcinoma HT-29 cells by carbon monoxide (CO) delivery from a Mn-based green luminescent photoCORM. Inorg. Chim. Acta 2019, 485, 112-117. [CrossRef]

86. Pinto, M.N.; Chakraborty, I.; Jimenez, J.; Murphy, K.; Wenger, J.; Mascharak, P.K. Therapeutic Potential of Two Visible Light Responsive Luminescent photoCORMs: Enhanced Cellular Internalization Driven by Lipophilicity. Inorg. Chem. 2019, 58, 14522-14531. [CrossRef] [PubMed]

87. Pinto, M.N.; Chakraborty, I.; Sandoval, C.; Mascharak, P.K. Eradication of HT-29 colorectal adenocarcinoma cells by controlled photorelease of $\mathrm{CO}$ from a CO-releasing polymer (photoCORP-1) triggered by visible light through an optical fiber-based device. J. Control. Release 2017, 264, 192-202. [CrossRef]

88. Chakraborty, I.; Carrington, S.J.; Roseman, G.; Mascharak, P.K. Synthesis, Structures, and CO Release Capacity of a Family of Water-Soluble PhotoCORMs: Assessment of the Biocompatibility and Their Phototoxicity toward Human Breast Cancer Cells. Inorg. Chem. 2017, 56, 1534-1545. [CrossRef]

89. Jackson, C.S.; Schmitt, S.; Dou, Q.P.; Kodanko, J.J. Synthesis, characterization, and reactivity of the stable iron carbonyl complex $[\mathrm{Fe}(\mathrm{CO})(\mathrm{N} 4 \mathrm{Py})](\mathrm{ClO} 4) 2$ : Photoactivated carbon monoxide release, growth inhibitory activity, and peptide ligation. Inorg. Chem. 2011, 50, 5336-5338. [CrossRef]

90. Niesel, J.; Pinto, A.; Peindy N’Dongo, H.W.; Merz, K.; Ott, I.; Gust, R.; Schatzschneider, U. Photoinduced CO release, cellular uptake and cytotoxicity of a tris(pyrazolyl)methane (tpm) manganese tricarbonyl complex. Chem. Commun. 2008, 1798-1800. [CrossRef]

91. Kawahara, B.; Ramadoss, S.; Chaudhuri, G.; Janzen, C.; Sen, S.; Mascharak, P.K. Carbon monoxide sensitizes cisplatin-resistant ovarian cancer cell lines toward cisplatin via attenuation of levels of glutathione and nuclear metallothionein. J. Inorg. Biochem. 2019, 191, 29-39. [CrossRef]

92. Kawahara, B.; moller, T.; Hu-Moore, K.; Carrington, S.; Faull, K.F.; Sen, S.; Mascharak, P.K. Attenuation of Antioxidant Capacity in Human Breast Cancer Cells by Carbon Monoxide through Inhibition of Cystathionine beta-Synthase Activity: Implications in Chemotherapeutic Drug Sensitivity. J. Med. Chem. 2017, 60, 8000-8010. [CrossRef]

93. Castano, A.P.; Mroz, P.; Hamblin, M.R. Photodynamic therapy and anti-tumour immunity. Nat. Rev. Cancer 2006, 6, 535-545. [CrossRef] [PubMed]

94. Chen, Y.; Gao, Y.J.; Li, Y.C.; Wang, K.; Zhu, J.T. Synergistic chemo-photodynamic therapy mediated by light-activated ROS-degradable nanocarriers. J. Mater. Chem. B 2019, 7, 460-468. [CrossRef] [PubMed]

95. Musib, D.; Raza, M.K.; Martina, K.; Roy, M. Mn(I)-based photoCORMs for trackable, visible light-induced CO release and photocytotoxicity to cancer cells. Polyhedron 2019, 172, 125-131. [CrossRef]

96. Chakraborty, I.; Jimenez, J.; Mascharak, P.K. CO-Induced apoptotic death of colorectal cancer cells by a luminescent photoCORM grafted on biocompatible carboxymethyl chitosan. Chem. Commun. (Camb.) 2017, 53, 5519-5522. [CrossRef] 
97. You, H.; Yoon, H.E.; Jeong, P.H.; Ko, H.; Yoon, J.H.; Kim, Y.C. Pheophorbide-a conjugates with cancer-targeting moieties for targeted photodynamic cancer therapy. Bioorg. Med. Chem. 2015, 23, 1453-1462. [CrossRef]

98. Astolfi, L.; Ghiselli, S.; Guaran, V.; Chicca, M.; Simoni, E.; Olivetto, E.; Lelli, G.; Martini, A. Correlation of adverse effects of cisplatin administration in patients affected by solid tumours: A retrospective evaluation. Oncol. Rep. 2013, 29, 1285-1292. [CrossRef] 